\title{
Ways of looking: Lexicalizing visual paths in verbs ${ }^{1}$
}

\author{
EWELINA WNUK \\ University College London \\ https://orcid.org/0000-0001-6683-2908
}

\begin{abstract}
The packaging of meaning in verbs varies widely across languages since verbs are free to encode different aspects of an event. At the same time, languages tend to display recurrent preferences in lexicalization, e.g. verb-framing vs. satellite-framing in motion. It has been noted, however, that the lexicalization patterns in motion are not carried over to the domain of vision, since gaze trajectory ('visual path') is coded outside the main verb even in verb-framed languages. This 'typological split' (Matsumoto 2001), however, is not universal. This article contains the first extensive report of verb-framing in the domain of vision based on data from Maniq (Austroasiatic, Thailand). The verbs are investigated using a translation questionnaire and a picture naming task, which tap into subtle semantic detail. Results suggest the meanings of the verbs are shaped by universal constraints linked to earth-based verticality and bodily mechanics, as well as local factors such as the environment and the cultural scenarios of which looking is a salient part. A broader look across the whole Maniq verb lexicon reveals further cases of verbally encoded spatial notions and demonstrates a pervasive cross-domain systematicity, pointing to the language system itself as an important shaping force in lexicalization.
\end{abstract}

Keywords:

lexicalization pattern, verb semantics, verbs of perception, path, fictive motion, systematicity 


\section{INTRODUCTION}

Lexicalization patterns in verbs vary widely across languages since verbs are free to encode different aspects of an event in their semantics (Gentner 1982, Talmy 1985, Gentner \& Boroditsky 2001, Evans 2011). While nouns are often claimed to be 'given' by the world in the sense that they represent stable and 'cohesive collections of perceptual information', verbs carry complex relational meanings that can be construed in a multitude of different ways (Gentner 1982: 46, see also Thompson, Roberts \& Lupyan 2020). Thus, for instance verbs of motion - aside from the fact of motion - can lexicalize a number of distinct components of the motion event, e.g. path, manner, figure (moving entity), and ground (reference entity) (Talmy 2000a). Verbs of physical separation, i.e. cutting and breaking, can encode manner, instrument, or type of separation (Majid et al. 2007, Majid, Boster \& Bowerman 2008). Verbs of ingestion, in turn, may code for the type of ingested matter, manner of ingestion, but also speed and intensity, or the consumed quantity (Newman 2009, Burenhult \& Kruspe 2016, Wnuk 2016b). In domain after domain, denotations of verbs show cross-linguistic variability and malleability of the underlying concepts. Still, despite the considerable variation, the packaging of meaning in verbs is not random as there are a number of factors which contribute to shaping the lexical verb categories (Malt \& Majid 2013).

One such factor is related to the recurrent PATTERNS of lexicalization exhibited by specific languages. For instance, in default descriptions of motion events, languages tend to use main verbs lexicalizing either path of motion (as in Spanish bajar 'to descend') or manner of motion (as in English roll). They were classified into verbframed (i.e. bajar-type) and satellite-framed (roll-type) languages (Talmy 1985, 2000a) on this basis, although these two patterns may be reversed in some contexts and do not 
exhaustively represent the typological picture. A third type - equipollently-framed languages - has since been distinguished and refinements have been proposed to accommodate the fact that languages can exhibit mixed patterns of motion event expression (Slobin \& Hoiting 1994; Slobin 2004; Zlatev \& Yangklang 2004; Levinson \& Wilkins 2006; Beavers, Levin \& Tham 2010; Selimis \& Katis 2010).

While the typology of motion verbs distinguishes a verb-framed pattern and a satellite-framed pattern, each found in a sizeable sample of languages from across the world, the picture seems to be different in the domain of visual perception. Here, the PATH of looking, i.e. gaze trajectory, is expressed externally to the main verb in both satellite-framed languages, e.g. English - look up and Polish - patrzeć w górę 'look-inup', and those that otherwise favour verb-framing, e.g. Spanish - mirar para arriba 'look-toward-up' and Turkish - yukarı bakmak 'upwards-look'. Slobin suggests 'verbframed languages do not provide specialized verbs for visual paths, on a par with "enter", "ascend", and the like; rather, both types of languages rely on all-purpose perception verbs such as "look," combined with various sorts of adjuncts (...)' (2009: 205). Matsumoto (2001) found the same pattern in a typologically diverse sample of languages (verb-framed, satellite-framed, equipollenty-framed): English, Spanish, Hindi, Japanese, Korean, and Thai, and referred to this situation as a 'typological split'.

The 'typological split' has been observed in the better-known verb-framed languages, but - as will be shown here - it does not represent a universal lexicalization constraint. Mentions of verbs of looking encoding trajectory of gaze (i.e. visual path) appear in the literature (Klein 1981, Evans \& Wilkins 2000), but the pattern appears to be typologically rare and, as of yet, it has not received systematic treatment. This article contains the first detailed documentation of the semantics of such verbs, making a 
descriptive and typological contribution to the verbs of perception literature. The central phenomenon examined here are the verbs of looking which encode visual path in Maniq (Austroasiatic, Thailand). Consider the following two spontaneous descriptions of looking events, illustrating the use of an upward-directed looking verb balay (1) and a downward-directed yop (2).

(1) Description of a tiger hunting for gibbons

PE? balot balay cey tawoh

3 be.under.sth look.up bum gibbon

'It's underneath, and looks up at the gibbon's bum.'

(2) Narrative about Maniq ancestors

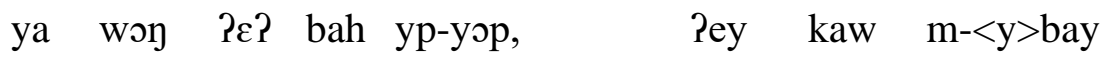

IRR child 3 go IPFV-look.down father PROX PROG-<IPFV >dig

'The child went looking down, the father was digging.'

Both balay and ysp have specific meanings and - in addition to lexicalizing the looking activity itself - carry information about the trajectory of looking. Such meaning specialization is in line with Maniq's general typological profile of a language with a semantically specific verb lexicon and a consistent preference for verbal encoding of information across a number of lexical fields such as motion, ingestion, transportation, and many others (Wnuk 2016a, 2016b). In many cases, the shape of the lexicon can be shown to be linked to cultural preoccupations and indigenous expert knowledge. The question here is whether a similar culture-language link might exist for verbs of looking. What pressures are shaping this vocabulary? And, related to that, what could be the possible communicative advantages of encoding path in verbs? 
Following earlier explorations (e.g. Slobin 2009, Cifuentes-Férez 2014), the present discussion of visual perception draws parallels to the domain of motion. Visual perception and motion have been noted to display a number of similarities. In Talmy's terms, visual perception is an example of FICTIVE MOTION - 'motion with no physical occurrence' (2000b: 99; cf. also Matlock \& Bergmann 2019), more specifically categorized as EMANATION, i.e. 'fictive motion of something intangible emerging from a source' (2000b: 105). ${ }^{2}$ The conceptualization involves an agent who 'volitionally projects his line of sight' (Talmy 2000b: 116) and is an active perceptual act (an activity-type predicate; Viberg 1984), rather than a passive experience. The observation regarding similarity of vision and motion rests on linguistic evidence showing motion and vision enter similar syntactic frames and occur with the same spatial expressions such as to and from (Gruber 1967, Jackendoff 1983, Slobin 2009, Gisborne 2010). Evidence for the fictive motion conceptualization of vision is found in numerous languages across the world and has been proposed to be universal (Slobin 2009: 199). While visual perception and motion display similarities, they are also clearly different from each other. Slobin (2009: 204-205) makes the following observation:

An act of looking doesn't bring about a change of locative state of the fictive agent or of the gaze as an extended entity. That is (at least from the point of view of an English speaker), when I look into another room, my gaze is still anchored at my eyes, and has not left me and achieved a new state of containment on the other side of the threshold. But if my dog goes into that room, he is no longer here at my side, but there, having crossed the boundary. That is, boundary-crossing is a change of state event for physical motion, but not for visual motion. 
Such fundamental differences between visual perception and motion could well result in different sets of constraints shaping the lexical categories across these domains, and ultimately help account for why visual paths in many verb-framed languages are resistant to verbal encoding. Maniq does lexicalize path information in verb roots in both verbs of motion and visual perception. However, the question remains whether the distinctive nature of the two types of events results in specific differences as to the types of lexicalized paths. What paths do verbs of motion and verbs of vision encode?

To address the above points, this paper explores in detail the expression of visual paths in Maniq and the extent of their parallelism to motion paths. To prepare the ground for comparison, I introduce Maniq and its speakers (Section 2) and provide a brief outline of the domain of motion event descriptions outlining basic facts about the expression of spatial relations in Maniq (Section 3). Following that, I introduce the central part of the present investigation - the verbal encoding of visual paths, explored by means of a translation questionnaire (Section 4.1) and a picture naming task (Section 4.2). These two tasks probe the distinctions of potential relevance to the domain of visual perception and bring out the semantic subtleties of the featured verbs. This information - contextualized within the local ecological and cultural setting - sheds light onto the organizing principles of the visual perception lexicon and the communicative utility of encoding path in verbs. The final sections contain a comparison of paths encoded in verbs of motion and verbs of vision (Section 5). The data show there is a core set of spatial distinctions lexicalized across the two verbal lexical sets. A broader look across the Maniq lexicon reveals parallel cases of such encoding (Section 6), thus demonstrating a pervasive systematicity in the packaging of meaning in verbs. 


\section{THE MANIQ LANGUAGE BACKGROUND}

Maniq (also known as Ten'en, Tonga or Mos; ISO: tnz) is a Northern Aslian language from the Aslian branch of the Austroasiatic family. It is spoken in Southern Thailand by approximately 300 people, most of whom live in small nomadic groups scattered across four provinces in the Banthad mountains (Wnuk 2016a). Maniq displays complex morphological processes such as combined reduplication and affixation. The default constituent order is SVO, with frequent argument ellipsis. Among its most characteristic features is a strong preference for encoding semantically specific information in monomorphemic verbs, a feature shared with other Aslian languages spoken to the south. Maniq can also be described as a 'verby' language, due to an almost equal oneto-one noun-to-verb ratio in the lexicon, and a prominent position of verbs in discourse (Wnuk 2016a).

The research reported here is based on first-hand fieldwork carried out by the author with a nomadic group of Maniq speakers in the Manang district, Satun province (Thailand). The translation questionnaire task was conducted in August 2012 and the picture naming task in February 2014.

\section{SEMANTICS OF MOTION VERBS IN MANIQ}

Maniq has a wide repertoire of motion verbs (as do other Aslian languages, e.g. Burenhult 2008, Kruspe 2010). This section focuses on a general delineation of the distinctions lexicalized in motion verbs. In particular, it provides an inventory of the commonly encoded semantic components of motion events and lists the types of motion paths encoded in verbs. The data presented here are based on non-elicited use as well as stimulus-based elicitation with 'Motion verb stimulus' clips (Levinson 2001). 
Based on the criterion of path encoding, Maniq can be classified as a verbframed language, since it lexicalizes path of motion in independent verbs (Talmy 1991). Consider examples (3) and (4) below with monomorphemic path-encoding verbs $c \varepsilon n$ 'to move along the top of an object', ciday 'to move uphill' and $s a$ 'to descend'.

\section{(3) Ball rolls up ramp}

Pद? cn-cen, (...) $\quad$ P $\quad$ ? ciday

3 IPFV-move.along.on.top 3 move.uphill

'It's moving along the top, (...) it's moving uphill'

(4) Ramp slides under ball

hayet $\quad$ $\varepsilon$ ? sa

yellow 3 descend

'The yellow one (the ramp) is descending.'

Manner information is frequently omitted in descriptions of these kinds, as is typical of verb-framed languages. When mentioned, manner is most typically lexicalized in independent verbs, occurring either in separate clauses or within multiverb constructions (with the manner verb following the path verb, as in (5), or preceding it). 
(5) Ball bounces over dyke

laykah kaloc

go.over jump

'(It) jumps over.'

This example suggests Maniq could be classified as a 'complex verb-framed language' (otherwise called equipollently-framed), characterized by the encoding of path and manner in two grammatically equivalent verbs (Slobin \& Hoiting 1994, Slobin 2004). However, a systematic investigation of motion events is needed to identify the predominant patterns and provide a nuanced typological characterization (cf. Slobin 2004, Levinson \& Wilkins 2006). The relevant fact for now is that path of motion is routinely lexicalized in verbs.

Aside from path and the fact of motion itself, some of the basic motion verbs in Maniq also lexicalize the component of ground (cf. Jahai; Burenhult 2008), e.g. wet 'to move downstream'. Such verbs are among the most semantically heavy items in the lexicon carrying multiple semantic components. Table 1 shows the motion verbs applying to different types of path and ground. All listed verbs lexicalize change of location, and none encode manner.

<insert Table 1 about here>

Note that among the categories in the table, some verbs lexicalize a specific type of ground (e.g. wet 'to move downriver'), while others are more general (e.g. sa 'to descend (general)'). Depending on the type of ground, the 'horizontal' category 
corresponds to ACROSS, e.g. patiy 'to go across a river', or ALONG, e.g. cen 'to move along the top of an object'. In addition to the distinctions given in the table, some categories, notably the arboreal motion verbs, also lexicalize manner, e.g. tanbon 'to climb a tree with a "walking" style"

Aside from UP, DOWN and ACROSS/ALONG, the following object-anchored paths have been found to be encoded in verbs:

(6) INTO/UNDER hok 'to enter/to go under'

OUT $\quad y \varepsilon s$ 'to exit'

BACK palin 'to turn back, to change direction of motion'

SIDEWAYS kapon 'to turn sideways, to change direction of motion'

OVER laykah 'to go over an obstacle'

NEXT TO/AROUND gagie 'to move around or next to the edge of an object'

The list is most likely not exhaustive since the domain of motion has not been fully explored, but irrespective of the actual number of existing verbs, the crucial observation is that object-anchored paths of motion are frequently lexicalized in verb roots.

Beyond verbs of motion, spatial figure-ground relations can also be expressed in other types of verbs, e.g. verbs of stative location expressing 'place' (cf. Svenonius 2010) such as $t u l$ 'to be inside a contained space'. Spatial relations are further coded in locative prepositions expressing source (natay 'from') and location/goal ( $d a$ ? / ki? 'on, in, at', niฤ 'in, on'), as well as in relational nouns (e.g. kapin 'upper side', kayom 'lower side', ka?ว? 'back') (Kruspe, Burenhult \& Wnuk 2015, Wnuk 2016). These elements combine within clauses in multiple ways. Relational nouns may occur on their own or 
with an optional preposition, e.g. (da?) kapin 'on top' (on upper.side). Similarly, verbs encoding spatial relations may be used on their own or with optional

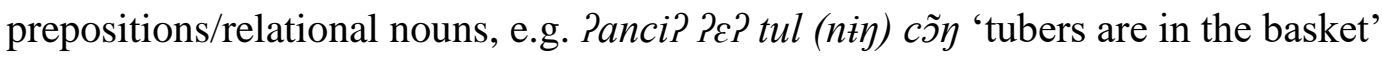
(tuber 3 be.inside (in) basket). Finally, in some cases it is also possible to leave the central spatial relation to be inferred from context, e.g. $2 \varepsilon$ ? cih ho? mahim 'it's (in) the coconut shell, the blood' (3 be.placed shell blood).

\section{SEMANTICS OF MANIQ VERBS OF LOOKING}

Having outlined the general distinctions relevant for the motion domain and the ways of expressing spatial relations in Maniq, I now turn to the domain of vision. Of major interest to this investigation is the question of path-encoding. What path distinctions are encoded in verbs of looking? And how do verbs of looking compare to verbs of motion and verbs in other semantic fields?

In order to survey the visual perception domain, two tasks were carried out with Maniq speakers: a translation questionnaire and picture naming. The translation questionnaire provided a first general indication of the available distinctions lexicalized in verbs of looking. Picture naming explored them further by establishing the exact extensional range of the verbs and testing which spatial frames of reference they are associated with.

\subsection{Study 1: Translation questionnaire}

\subsubsection{Method}

The initial probing of the distinctions encoded in verbs of looking was carried out with the use of a translation questionnaire. Two male speakers of Maniq aged approximately ${ }^{4}$ 35 and 45 took part in the task. 
The questionnaire was composed of 59 sentences in Thai containing simple descriptions of looking events. The sentences examined a broad selection of visual paths as judged by gaze direction. It included paths which are known to be relevant for verbs of motion (Section 3), as well as several other paths expressing spatial distinctions of high salience in the Maniq community (e.g. east, west). Note that some spatial distinctions are ambiguous with respect to the spatial coordinate system ('frame of reference') they typically associate with (i.e. egocentric vs. absolute). This could not be explored systematically in this task, but the issue is treated more extensively in Section 4.2 .

- Horizontal: STRAIGHT, SIDEWAYS, BACK

- Vertical: $\quad$ DOWN, UP

- Horizontal+Vertical AROUND

- Object-anchored: AT, INTO, OUT, UNDER, OVER, THROUGH, ALONG, ACROSS

- Absolute: $\quad$ EAST, WEST

Example sentences are provided in (7). The full questionnaire (in English and Thai) is included in Appendix 1.

(7) The man looked up the tree in search of leaf monkeys.

The deer looked back when it heard a noise coming from behind.

I couldn't find my machete, so I looked under the bed to check if it was there.

In addition to the selected types of paths, the stimulus set varied parameters such as the type of ground object (e.g. tree, stream), the type of viewed object, i.e. endpoint of 
visual path (e.g. person, animal, thing), identity of the experiencer (human, animal), position of the body (e.g. standing, sitting, lying), and position of the eyes (neutral, up, down, sideways). The purpose of this broad selection of stimuli was to identify the relevant parameters lexicalized in the Maniq verbs of looking and to eliminate irrelevant ones.

The first half of the questionnaire was administered to both participants interviewed together in a single session. The second half was administered on another day to the older participant (due to the unavailability of the younger participant). The focus of the elicitation was not an exact translation of the entire scenario described in the sentence, but only of the target descriptions of looking events and visual paths. In addition to providing translations, the participants answered questions and judged the acceptability of alternative descriptions provided by the experimenter. This information was used as additional evidence supplementing the results from translation. The Thai sentences were read out by a native speaker of Southern Thai, while the additional probing was carried out in Maniq by the experimenter. The section below contains a summary report of the main results.

\subsubsection{Results}

The translations yielded a total of eight verbs used as independent descriptors of the looking actions (8). Seven of them encoded specific horizontal and vertical gaze directions, and one - $d \varepsilon \eta$ - was a direction-neutral general looking verb. All listed verbs are monomorphemic, except for $w w \varepsilon$, which contains an imperfective affix. In addition, ciyc̃k and cikiey - though synchronically non-analyzable - appear to share a fossilized prefix ${ }^{*} c$ - and the causative infix $\langle i>$. 
(8) balay look up

pəntew look up/straight

ciyẽk look sideways

cikiey look sideways/back

wwe look around

pədep look around jerkily like a bird

yop look down

dey look (direction-neutral)

The elicitation revealed further that distinctions such as absolute directions (east-west), type of ground (e.g. tree, stream), and type of viewed object (e.g. liquid-solid) were not lexicalized in verb roots but were expressed by other lexical means. Object-anchored paths (e.g. to look under something) were also not associated with dedicated verbs but were either unexpressed or expressed periphrastically. The identity of the experiencer was not lexicalized in the verb. There were some indications that parameters such as body posture and position of the eyes had a meaningful influence on the verb choice, but - given that no clear generalizations emerge - the issue was explored further in the picture naming task.

There is no evidence to suggest responses may have been influenced by the way looking events are expressed in Thai. Most of the looking event descriptions in Thai were made up of the general looking verb mong 'to look' followed by one of the pathencoding elements such as a motion verb (e.g. khâo 'to enter'), a preposition (e.g. tâi 'under'), or an adverb (e.g. khâng lâng 'below, down'). There were no word-for-word 
translations or consistent correspondences between Thai and Maniq, suggesting the Thai patterns did not shape the responses provided.

The most semantically general looking verb was $d \varepsilon \eta$. Rather than being

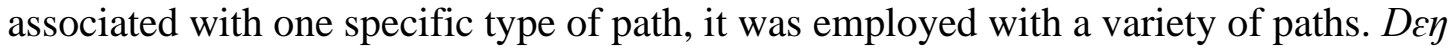
was in most cases attested in a bare root form (9). Only in one case, did it surface in the imperfective form $d \eta d \varepsilon \eta$. The imperfective - signalling the ongoingness of the action was used to express 'looking around' (10).

(9) \#20 looked inside the blowpipe

dey nin hanrey balaw

look.at in hole blowpipe

'(He) looked inside the blowpipe'

(10) \#10 looking sideways from time to time

Pin $\mathrm{dy}-\mathrm{d} \varepsilon \eta$

1S IPFV-look.at

'I was looking around'

Balay was used to express looking up. It was attested both with simple UP paths $(11)^{5}$, as well as complex ones, e.g. UP INTO, and paths with a specific ground such as UPHILL.

(11) \#2 looked up the tree

mi? sawe balay yut

INDF search look.up stump-tailed.macaque 
'The (Maniq) person searched for stump-tailed macaques looking up.'

Another verb expressing the meaning of looking up was pantcw. Example (12) below was elicited with a sentence involving a woman looking out from a house. In this case, the participants presupposed the house was on a slope and explicitly stated pantew would be appropriate if the woman was looking upwards (while looking downwards would require the verb yəp, see below). Pantew refers to looking up, but it seems to differ from balay since the two verbs occurred in different contexts. This difference is examined further in the picture naming task (Section 4.2). Additional probing revealed pəntew is also associated with looking straight ahead. This suggests the verb covers a range of gaze directions encompassing straight level and upward paths.

(12) \#24 looked out from the house

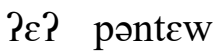

3 look.up/straight

'She looked up (ahead of her)'

The verbs ciyc̃k and cikiey were both employed to express looking sideways, e.g. ciyc̃k in (13). Cikiey was additionally employed with BACK, as in (14).

(13) \#12 turned her head sideways and looked

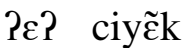

3 look.sideways

'She looked sideways' 
(14) \#16 looked over his shoulder

?ह? wa cikiey gana?

3 walk look.back companion

'He walked looking back at his companions'

Two other verbs $-w w \varepsilon$ and $p a d \varepsilon p-$ were used to express looking around. Wwelike $d \eta d \varepsilon \eta$ mentioned above - is an imperfective form (derived from $w \varepsilon$ 'to walk around looking for food') and indicates an ongoing looking activity. Padcp also expresses the activity of looking around, but it additionally denotes a manner of looking involving sudden jerky movements characteristic of birds.

(15) \#14 began looking around

PE? W-we ha, $P \varepsilon ?$ doh ha

3 IPFV-look.around path 3 lose path

'He was looking around for the path, he lost the path.'

(16) \#15 (bird) was looking around

kawaw $2 \varepsilon ?$ podep

bird 3 look.around.jerkily

'The bird was looking around jerkily'

$Y э p$ was used to express looking down. It was employed in translations of sentences explicitly specifying a downward gaze trajectory, as well as those where it was presupposed based on sentential context, e.g. looking into a basket (17), or under a bed. 
(17) \#18 looked into (basket)
२ह? ур-уэр
cว̃y
3 IPFV-look.down basket
'She looked down (into) the basket'

To summarize, 'looking' was translated into a number of specific verbs encoding visual path and - in a few cases - other semantic detail. This preliminary evidence suggests these verbs mark directions such as UP, UP/STRAIGHT, SIDEWAYS/BACK, and AROUND without accompanying spatial expressions external to the verb. The path distinctions identified in the core set of verbs are explored further in a systematic investigation carried out with a picture naming task.

\subsection{Study 2: A picture-naming task}

Picture naming involved descriptions of a selection of looking scenes. It focused on distinctions which were difficult to test with verbal stimuli, but were relatively easy to depict using visual representations, e.g. small variation in angle of gaze, presence/absence of an endpoint object, varying body posture, and position of the eyes. This was done to establish the exact extensional range of the verbs and identify their distinctive features (especially since some of them seemed to overlap in denotation, e.g. balay and pantew). In addition, this task set out to determine what spatial coordinate systems ('frames of reference') the looking verbs are associated with. The translation task revealed that, for instance, ysp refers to looking down and cikiey to looking sideways, but it is unclear whether these directions are determined with respect to the viewer's body or the environment. Since the issue of frames of reference is of 
importance to this task, the following section introduces it briefly, situating it in the context of looking events.

\subsubsection{Frames of reference in looking events}

Frames of reference are coordinate systems applied for computing spatial relationships between objects (Levinson 2003, Majid et al. 2004). In the context of looking events, different frames of reference are associated with different ways of determining the trajectory of gaze. Two types of frames of reference will be relevant to the ensuing discussion: EGOCENTRIC (or viewer-centered) and ABSOLUTE (or environment-centered) (cf. Carlson-Radvansky \& Irwin 1993). ${ }^{6}$ The egocentric frame is viewer-centered, i.e. the defining relation is based on the alignment of viewer's bodily axes with respect to one another. The relation which will be critical here is the angle between the head and the spine resulting from head rotation (turning), and head flexion (bowing). An additional parameter of relevance is the position of the eyes with respect to the face. The absolute frame, in contrast, is environment-centered, i.e. the defining relation is specified by the angle between gaze direction and the absolute vertical axis, determined by gravity and salient environmental features. Figure 1 and Figure 2 illustrate the distinction.

<Insert Figure 1 about here> <Insert Figure 2 about here>

Normally, bodily and absolute axes align. So, in canonical instances of various looking acts, there is no need to pick between frames of reference in order to select which verb to use. However, in non-canonical cases - where bodily and absolute axes do not align, e.g. when lying down - the speaker is forced to assume either an 
egocentric or absolute perspective, as either choice will require the use of a different verb. Misalignment of frames of reference is a common problem in spatial language, since languages typically do not have dedicated strategies for non-canonical cases. For instance, the English preposition above is applied with the absolute or intrinsic (i.e. object-centered) frame of reference, depending on which perceptual cues are used to define the vertical axis (Levelt 1984, Carlson-Radvansky \& Irwin 1993). The picture naming task tackles this problem directly by introducing experimental manipulations teasing apart egocentric and absolute frames via non-canonical body postures accompanying looking scenes.

\subsubsection{Method}

Eight participants (4 male, 4 female) in the approximate age range of $27-65$ took part in the picture naming task. All were native speakers of Maniq. The stimuli were 54 photographs: 50 looking scenes and 4 closed-eyes scenes (see examples in Figure 3; and the full set in Appendix 2). Because the closed-eyes scenes were added later, they were administered with only 4 of the 8 participants. The remaining 50 scenes were described by all 8 participants. Each looking scene involved one person (either male or female) looking in a particular direction. Most photographs were taken indoors against a neutral background to maximize the focus on the looking act and discourage inferential descriptions such as 'He is searching for animal tracks'.

<Insert Figure 3 about here> 
The stimuli explored four types of visual paths as judged by gaze direction.

Table 2 below contains a visual summary of the combinations of horizontal, vertical, and diagonal paths targeted in the stimuli (the grayed-out area).

- Horizontal: $\quad$ STRAIGHT, LEFT, RIGHT, BACK

- Vertical: $\quad$ LEVEL, DOWN, UP

- Diagonal: DOWN-and-LEFT, DOWN-and-RIGHT, DOWN-AND-BACK, UP-and-LEFT, UP-and-RIGHT, UP-AND-BACK,

- Object-anchored: AT, INTO, OUT, UNDER, OVER, THROUGH, ALONG, ACROSS

<Insert Table 2 about here>

To address the issue of frames of reference, the scenes also varied parameters such as position of the body (e.g. standing, lying on belly/back/side, leaning) and position of the eyes (neutral, up, down, right, left). An additional manipulation consisted of scenes with and without physical endpoints. This was done to examine whether presence of endpoints influenced the choice of verb and if the relevant verbs can surface with direct objects. Some scenes additionally varied type of ground object (e.g. stairs, mound, tree), since some grounds are culturally more salient and might be associated with special strategies. Finally, to probe the scope of the verbs, SHARP $\left(\sim 90^{\circ}\right)$ and NONSHARP $\left(\sim 45^{\circ}\right)$ angle variants of LEFT, RIGHT, DOWN and UP were included. For practical reasons to keep the stimulus set to a manageable size, only some combinations of these parameters were included (for the full list of stimuli, see Appendix 2). 
Participants saw photographs one by one in a fixed random order on a 14-inch laptop. The task was to answer the question $? \varepsilon$ ? di? kalaw 'What is he/she doing?' (3 do what) for each image. The length of the response was not restricted so speakers were free to use as many verbs as they wished in their descriptions. If no reference to the looking act was made, the experimenter provided descriptions for judgment or asked additional questions. The prompted answers were not included in the main count, but were occasionally used as auxiliary evidence to support the analysis. The whole procedure was carried out in Maniq.

In addition to the picture naming task, the Maniq verbs of looking were explored by having a few speakers enact them. These re-enactments were done informally on a separate occasion, both by speakers who participated in picture naming as well as those who didn't. Speakers were asked to enact situations using a simple instruction consisting of a verb in a simple imperative frame msh $x$, e.g. msh balay 'look up' (2S

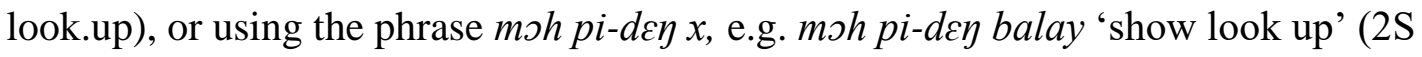
CAUS-see look.up). Insights from the re-enactments were used as supporting evidence for the interpretation of the results presented below.

\subsubsection{Results}

The stimuli successfully elicited descriptions of the looking acts from the majority of participants. The provided descriptions were generally short, often consisting of a single clause or several clauses (maximally 5). Example responses are given in (18) and (19) below.

(18) $2 \varepsilon ? \quad m-<p>y \supset p$

$3 \quad$ PROG-<IPFV>look.down 
'He is looking down' (\#37)

(19) ? $\varepsilon$ ? $t<m><$ i $><$ P $>$ pa?

$\mathrm{m}-<\mathrm{p}>$ yəp

3 lie.on.belly $<$ PROG $><$ CAUS $><$ IPFV $>$ PROG- $<$ IPFV $>$ look.down

$\mathrm{p}<\mathrm{m}>\mathrm{u}<\mathrm{w}>\mathrm{t} \varepsilon \mathrm{w}, \quad$ met $\quad$ da? $\quad$ ? $\varepsilon$ n

look.straight $<$ PROG $><$ IPFV $>$ eyes LOC DEM

'He is lying on belly and looking down, (he's) looking straight ahead, eyes here.' $(\# 24)$

Most clauses were brief and typically consisted only of the subject and predicate.

Subjects were occasionally omitted, in which case the description was minimal, i.e. consisting of the predicate only. Predicates were either simple and formed by single verbs, or complex and formed by multi-verb constructions, e.g. tmi?pa? mpyəp in (19). Most verbs were derived with the progressive morpheme (and sometimes also the imperfective), suggesting the looking events were encoded as ongoing (cf. Wnuk 2016a).

As in the translation task, in most looking scene descriptions the information about the visual path was encoded solely in verbs. The verb was sometimes accompanied by overt expressions of visual path or goal. These included:

i) directional PPs (present in $11 \%$ of descriptions), e.g. hway haysl 'straight ahead' (towards be.straight)

ii) overt nominal locations (present in $12 \%$ of descriptions), introduced as PPs in case of relational nouns, e.g. da? kayom 'down' (LOC upper.side), and as bare nouns, e.g. nahu? 'at the tree' (tree), or PPs, e.g. niø hayã? 'in the house' (in/on house), in case of ordinary nouns, the two options occurring in free variation 
iii) deictic PPs (present in 7\% of descriptions), e.g. da? ?En 'here' (LOC DEM.here), $d a$ ? ? $u m$ 'there' (LOC DEM.there)

The majority of the descriptions, however, did not contain overt path or goal expressions. Crucially, the directional verbs of visual perception occurred predominantly without such expressions, consistent with the idea that the path was already encoded in the verb roots. For instance, the verb yəp, glossed as 'to look down', was employed 85 times in total, and only 7 times with the locative PP da? kayom 'down', as in (20).
(20) $P \varepsilon ? \quad m-<p>y \supset p$
da? kayom
3 PROG-<IPFV>look.down LOC bottom

'He is looking down.' (\#43)

Since da? kaysm 'down' expresses the visual goal, already implicit in the pathencoding verb yəp 'to look down', yəp da? kaysm might be thought of as a pleonastic expression, similar to the motion expressions subir arriba 'ascend up' and salir afuera 'exit out' described for Spanish (González Fernández 1997) or bike mesa 'she/he entered inside' for Greek (Selimis \& Katis 2010). The function of directionals in the Spanish case is associated with discourse prominence. Given that in the present data set the phenomenon is rare and not clearly linked with particular scenes, I will not pursue the issue further.

Instead, I turn to the main focus of the task - the path distinctions lexicalized in the verbs. In order to begin to explore them, verb frequency per stimulus was calculated. It was then possible to identify the verbs used most frequently with each scene. Most of 
the verbs employed in this task were the same as in the translation questionnaire, supporting the validity of the translation questionnaire as a means of identifying the relevant verbs. Only wwe 'to look around' and padcp 'to look around jerkily' from the previous task were not elicited in this task as these actions would require dynamic stimuli. Eight verbs were identified as relevant to the target event, of which six were looking verbs. In addition, four verbs referred to other events which are not directly relevant here, and therefore excluded from further discussion: hanyan 'to stand', tapa? 'to lie on belly', tiek 'to lie on back', and cep 'to touch/grasp with hand'. Table 3 lists the relevant eight verbs together with glosses, the list of scenes for which they were the dominant response, and the level of participant agreement (the percentage of participants who used the verb with a given scene). ${ }^{7}$

Most scenes were associated with a single dominant response. The exceptions were scenes \#4, \#5, \#8, \#21, \#23, \#27, and \#51, where two or three dominant responses were used an equal number of times. These scenes are listed several times, separately for each relevant verb. Stimuli, referenced by numbers, can be viewed in Appendix 2 . The discussion is divided into two sections: looking verbs and other verbs.

Before proceeding, several general points on visual paths are in order. Although similar to paths of motion in some respects, paths of vision have certain fixed properties determined by the nature of visual perception events. All paths of vision presuppose a perceiver, a point which constitutes the origin of the visual path. Hence, all verbs of vision lexicalize a deictic center, akin to the reference object lexicalized in the directed motion verb go (cf. Rappaport Hovav 2014). The fictive motion entailed is thus always directed away from the perceiver. Other elements of the path - discussed below 
separately for each verb - are determined by sentential complements or are recoverable from context.

\section{<Insert Table 3 about here>}

\subsubsection{Visual perception verbs}

(i) $d \varepsilon \eta$ 'to look at, to see'

The verb $d \varepsilon \eta$ is a direction-neutral gaze descriptor, as indicated by the fact it was employed with all sampled gaze directions. It was the most frequent verb in the task, used at least once with 47 of the 54 scenes. $D \varepsilon \eta$ is associated primarily with looking at particular objects and featured most often with object-anchored paths: UP-INTO-bag (\#32; Figure 4 B), DOWN-INTO-bag (\#35; Figure 4 C), LEVEL-INTO-bag (\#40), ATfingernails (\#2; Figure 4 A), AT-paper (\#28). It presupposes a path with an endpoint, though the endpoint itself need not be explicitly mentioned. In this sense, $d \varepsilon \eta$ differs from most other verbs featured in the task, which place emphasis on the path itself and lack inherent endpoints.

<Insert Figure 4 about here>

Note that images similar to those in Figure 4, but without specific physical objects as visual goals, elicited the direction-encoding verbs pəntew, yəp and balay. When visual goals were present, most participants did not encode direction, but focused on the endpoint by employing $d \varepsilon \eta$, suggesting visual perception events might be exhibiting a goal bias similar to the one observed for motion events (cf. Stefanowitsch \& Rohde 2004). 
$D \varepsilon \eta$ covered both AT- and INTO-type paths without making a distinction between the two. No special expressions were used to mark the crossed boundary ${ }^{8}$ of INTO in the two looking-INTO-bag scenes, consistent with Slobin's (2009) observation that boundary-crossing in visual perception is not a change-of-state event and - unlike in motion in verb-framed languages - it does not necessitate expression by a separate verb. The endpoint physical objects in both AT and INTO scenes surfaced as direct objects in the sentences.

(ii) pantcw 'to look ahead (for a general scene overview)'

The verb pantew is associated with looking ahead for a general overview of the scene in front. It is linked to neutral gaze directions (\#38; Figure $5 \mathrm{~A}$ ) and incorporates also nonsharp upward (\#1; Figure 5 B) and sideways angles. Pəntew can also be used with looking down from an elevated point such as stairs or mound, but not with the ordinary DOWN scenes, consistent with the idea that it applies with looks aimed at getting a general scene overview. Pantew was attested in scenes with various body-to-head angles (as in \#38, \#1, and \#20; Figure 5 A-C), which indicates the up-down gaze orientation is determined with respect to the absolute frame. However, it is also partially dependent on the egocentric frame since it encompasses an area in front projected from the body.

$<$ Insert Figure 5 about here $>$

Looking straight ahead is in a sense neutral, but the delimited distribution of pantew shows the verb is not insensitive to direction like the generic verb $d \varepsilon \eta$, which was used with almost all stimuli. In addition, during the extra probing in the task, 
pəntcw was used several times as a self-contained answer to the experimenter's question Where is he looking?, demonstrating sensitivity to a specific gaze trajectory (21).

(21) E: $₹ \varepsilon ?$ den da?.?a?

3 look where

'Where is he looking?

P: $\quad$ P $\varepsilon ? \quad \mathrm{p}<\mathrm{m}>\mathrm{u}<\mathrm{w}>\mathrm{t} \varepsilon \mathrm{W}$

3 to.look.straight/horizontally $<\mathrm{PROG}>\langle\mathrm{IPFV}\rangle$

'He is looking straight ahead.' (\#21)

(iii) cikiey 'to turn one's head sideways/back, to look sideways/back'

The verb cikiey is associated with the egocentrically-defined sideways and backwards gaze directions. It was employed to describe the simple sideways/back gaze paths - e.g. the scenes LEFT_SHARP (\#26; Figure 6 A) and BACK_via_right (\#13) - as well as some diagonal paths - e.g. BACK_and_DOWN_via_right (\#46; Figure 6 B). Note that BACK here entails turning the head and twisting the trunk, rather than turning the whole body together with the feet. The verb was not employed with a scene involving looking sideways by moving the eyes only, which suggests the rotated position of the head is a crucial aspect of cikiey.

$<$ Insert Figure 6 about here>

The image with a sharply turned head and closed eyes (\#53) was also described as cikiey, suggesting it might be acceptable to use the verb to refer to posture alone. This 
stimulus, however, might be depicting a somewhat unnatural situation, so this result should be interpreted with caution (participants may have, for instance, assumed the person was in fact gazing, but the photograph was taken during a blink).

Canonical examples of cikiey, as enacted by Maniq speakers, involve both head rotation and gaze (as in Figure 6 A). Gazing is thus presupposed for cikiey. Note also that cikiey can take visual goals as direct objects, e.g. cikiey gana? 'looking back at companions' (look.back companion) in example (14) attested in the translation task. Finally, cikiey can also occur in a special format, with the noun $m \varepsilon t$ 'eyes' in the direct object position, to place additional emphasis on gaze, as in (22). A similar format with the noun hoh 'neck' (23) is available for placing emphasis on the head turn.

$\begin{array}{lllll}\text { PE? } & \mathrm{c}<\mathrm{m}>\text { ikiey } & \text { da? } & \text { Pom } & \text { met } \\ 3 & \text { turn.head }<\text { PROG }>\text { LOC } & \text { DEM } & \text { eyes }\end{array}$

'He is turning his gaze there (far away) sideways.' (\#13)

(23) $2 \varepsilon ? \quad c<m>$ ikiey hoh

3 turn.head $<$ PROG $>$ neck

'He is turning his neck sideways.' (\#46)

(iv) ciyc̃k 'to look sideways, to move one's eyes to the side' The verb ciyčk is associated with a sideways gaze direction. It was the dominant response for only one scene - looking right by moving the eyes to the side (\#6) (Figure 7). 
The verb refers specifically to the movement of the eyes and their resultant position. This is especially apparent when it surfaces in the form calyz̃ (attested on a separate occasion in the phrase met calyc̃k 'eyes looking sideways' (eyes look.sideways.MULT)). This form contains a multiplicity infix $l$, encoding distribution of the action over multiple entities (in this case the two eyes) (see Wnuk 2016a: 87-88). Although the verb was a dominant response only in RIGHT_just_eyes scene, it was also applied - albeit less frequently - in scenes with a turned head (always with a lateral eye movement). This is related to the fact that head rotation is usually accompanied by lateral eye movement.

(v) balay 'to look up sharply'

The verb balay is associated with a sharply upward gaze, used with both simple upward paths and diagonal paths (\#15,\#31,\#39; Figure 8 A-C). The prototypical example of the verb involves gazing upwards with a sharply tilted head, as in the UP_SHARP scene (Figure 8 A). This is how speakers typically enact balay. However, balay does not require a tilted head (see e.g. Figure 8 B), which suggests UP is determined on absolute basis rather than egocentrically. The angle between the spinal axis and the vertical head axis is therefore not relevant, but what the verb is sensitive to is the environmentallydefined UP. In most everyday situations, UP means towards the tree canopy as looking upwards is saliently associated with foraging activities related to trees, e.g. hunting arboreal game, collecting fruit, etc. Non-elicited instances of the verb in my corpus involve predominantly such contexts, i.e. in four of the six recorded sessions featuring balay, it is used either in the context of hunting or collecting fruit (see example (1)). This is most likely the reason why balay associates with sharp gaze angles much more strongly than with non-sharp ones (see further 4.3.1). Although in this task balay 
surfaced mostly on its own, it can take direct objects expressing the visual goal, e.g. balay cey tawsh 'look up at gibbon's bottom' (look.up bottom gibbon), cf. example (1).

\section{$<$ Insert Figure 8 about here>}

While the primary sense of balay is 'to look up sharply', there is a possibility it could also be applied in an extended sense of 'to tilt one's head sharply', as suggested by the fact it was used with a closed-eyes scene (\#52). Note, however, that, as stated for cikiey, the closed-eyes stimulus might have been unnatural from the perspective of Maniq speakers. The unusualness of the scene was also reflected in the explicit qualification of responses by some speakers, who combined balay into a multi-verb construction with lep or nup, both meaning 'to close eyes'.

(vi) yəp 'to look down'

The verb yəp refers to downward gaze direction. It was employed with most scenes depicting looking downwards. They included looking down in various positions involving different body-to-head angles: while lying on belly (\#9; Figure 9 B), standing upright (\#44, \#37; Figure 9 A), lying on side, leaning forward, leaning down, crouching (\#19; Figure 9 C), and lying on back. This indicates yəp - like balay - is determined with respect to the absolute and not egocentric frame of reference. Yэp applies also with diagonal paths such as DOWN-and-RIGHT (\#43) and complex DOWN paths such as DOWNUNDER (\#19; Figure 9 C). It was also used for bowing the head without gazing (\#54), but as mentioned above, the significance of this pattern is unclear given the unnaturalness of this action and the fact that it's easy to mistake it for a gazing situation since the eyelids are down in both situations. In actual everyday use, yəp typically features in the context 
of foraging, e.g. tuber-digging, or is used with reference to people, monkeys and various tree animals looking down to the ground. For instance, in my Maniq corpus the verb occurs in such contexts in three out of the four recorded sessions in which non-elicited examples of yop were attested (see e.g. (2)).

$<$ Insert Figure 9 about here>

\subsubsection{Other verbs}

(i) cakip 'to bow one's head sharply'

The verb cakip is associated with bowing one's head sharply (\#30, Figure 10). Its primary reference is posture so it does not refer specifically to gazing, but it is discussed here because of its strong implication of a downward visual path. Given that the activity of bowing one's head sharply prototypically co-occurs with looking down, gazing is usually presupposed when cakip is used. Hence, while the downward gaze path is associated mainly with the verb yəp, cakip is confined to cases involving bowing one's head sharply. Occasionally, however, speakers form complex predicates combining it with ysp and making the information about gaze explicit, as in (24).

(24) $c<$ m>akip

$\mathrm{m}-<\mathrm{p}>$ yəp

bow.head.sharply $<$ PROG $>$ PROG- $<$ IPFV $>$ to.look.down

'(He) is bowing his head sharply and looking down.' (\#44)

$<$ Insert Figure 10 here> 
Unlike the other vertical-path verbs - balay and ysp, cakip is defined egocentrically, i.e. it is dependent on the angle between the spinal and head axes, resulting from head flexion (bowing). Cakip is also associated with the default body posture and motion of some terrestrial animals, e.g. turtles and frogs, and is additionally employed in the sense of an existential verb with those animals, e.g. baliw hic cakip 'there are no frogs' (frog NEG bow.head).

(ii) piwe 'to lurk, to look sneakily, e.g. from a hiding place' The verb piwe refers to looking sneakily, often from a hiding place. It was the dominant response for the scene depicting looking OUT of a room (\#11; Figure $11 \mathrm{~A})$. It was also occasionally elicited by its mirror image - looking INTO a room - as well as looking UNDER a chair while crouching. All situations were to some extent reminiscent of a canonical example of piwe, acted out by a Maniq speaker in Figure 11 B below.

<Insert Figure 11 about here>

Formally, piwe is a causative of $w \varepsilon$ 'to walk around looking for food' (usually attested in the imperfective form $w w \varepsilon$ (Section 4.1.2)). However, its meaning appears to be more specific than that associated with a regular causative derivation (Wnuk 2016a: 77-79), suggesting a degree of idiomaticity. Because of its strong link to the foraging context, its semantics is likely richer than this task was able to uncover. While visual path information is certainly present in the prototypical uses of the verb, it is not clear to what extent it is part of the core lexical meaning. ${ }^{9}$ Based on speaker's enactments which always involve looking from behind a specific physical object - the verb might encode an object-anchored path FROM BEHIND, but its occurrence with other types of 
paths suggests it is only loosely associated with a prototypical path and is better conceived of as a manner verb relating to looking sneakily.

\subsection{Summary and discussion}

The evidence from both the translation questionnaire and picture naming task revealed a core set of looking verbs incorporating information about visual path. These include verbs used with vertical, horizontal, and diagonal paths - pəntew, cikiey, ciyẽk, balay, $y \supset p$, wwe, and padcp (Section 4.3.1) - and verbs used with object-anchored paths $-d \varepsilon \eta$ (Section 4.3.2).

\subsubsection{Vertical, horizontal, and diagonal paths}

Table 4 is a graphic summary of the distinctions made by verbs referring to vertical, horizontal and diagonal paths, based on the dominant responses in the canonical scenes from the picture naming task ('canonical' here refers to scenes with neutral posture, in which change of gaze trajectory is accompanied by head movement). The only exception is the verb ciyc̃k 'to look/move eyes sideways', which is associated more closely with the position of the eyes rather than the head and is added here based on dominant responses to a non-canonical scene (\#6).

<Insert Table 4 about here>

Pantew covers the most neutral STRAIGHT-and-LEVEL gaze direction as well as slight $\left(\sim 45^{\circ}\right)$ upward and sideways gaze angles. The three main verbs covering nonneutral directions are balay, yəp and cikiey. Balay is associated with UP, yəp with DOWN, and cikiey with SIDEWAYS/BACK. Despite having largely corresponding denotations, these verbs differ in subtle semantic detail. While yəp is used with a relatively slight 
downward angle of gaze, balay and cikiey require more pronounced UP and SIDEWAYS angles. Balay has the broadest application and includes various examples of looking up and tilting one's head back. Cikiey, on the other hand, covers all instances of gazing sideways and back as long as they are accompanied by head turns. Yэp refers to gazing downwards, but if the action involves bowing the head sharply, cakip is preferred.

Not included in Table 4 are two other verbs: $w w \varepsilon$ 'to look around' and padep 'to look around jerkily', which featured in translations but not in picture naming. Based on the attested uses of these verbs, they are tentatively analysed here as path-encoding looking verbs expressing the notion of AROUND, with $p a d \varepsilon p$ additionally expressing manner. However, given that only a few instances of these verbs were attested, further investigation is needed to confirm if indeed they encode visual path. The issue is of particular relevance not only to the typology of perception verbs, but also more broadly, especially in the case of $p \partial d \varepsilon p$, in that it can speak to the debate in verb semantics literature regarding whether both manner and directed path (result) meanings can be lexicalized together (cf. Jackendoff 1985; Hovav \& Levin 2010; Beavers \& KoontzGarboden 2012).

Note that LEFT, RIGHT and BACK, as encoded in the verbs above, are egocentric, i.e. derived from bodily axes of the perceiver, while UP, DOWN and LEVEL are absolute, i.e. determined with reference to gravity and environmental features. Only cakip, despite implicating a downward visual path, is tied to bodily axes. It differs from the other verbs in this set since it is primarily related to body posture rather than gaze. ${ }^{10}$

Since the egocentrically-defined verbs - i.e. cikiey, cakip, ciyc̃k - are associated with specific body postures (and in the case of ciyčk, position of the eyes), the partitioning of visual paths is partially dictated by bodily mechanics. For instance, the 
fact that cikiey encompasses the lateral and backward directions can be explained by the perceptual similarity of the head movement involved in these two gaze trajectories.

Apart from the body, an important factor shaping the semantics of verbs in this set is earth-based verticality and environmental features. The fact that vertical verbal categories exist is linked to our bipedalism and ultimately accounted for by gravity (Miller \& Johnson-Laird 1976, Lyons 1977, Brown \& Levinson 1993). It is not immediately obvious, however, why the Maniq verbs of looking partition gaze directions the way they do. To recall briefly, balay denoting an upward gaze path refers only to sharp $\left(\sim 90^{\circ}\right)$ gaze angles, yəp denoting a downward gaze path refers both to mild and sharp angles $\left(\sim 45-90^{\circ}\right)$, and pantew covers all that is in between, i.e. level and mildly upward $\left(\sim 45^{\circ}\right)$ paths. To understand this division, one needs to take into account culture-specific factors since local functional considerations can shed light on the semantic structuring of spatial categories in languages (cf. Coventry, Carmichael \& Garrod 1994; Levinson, Meira \& The Language and Cognition Group 2003; Feist 2008).

Looking high up (balay) into the tree canopy is a salient activity accompanying many of the daily foraging practices (e.g. hunting arboreal game, collecting honey, fruit, bamboo for blowpipes, etc.). Since the forest is often dense and most of the desired objects are situated high in the canopy, one is typically forced to gaze up at a sharp angle.

Looking sharply up (balay) is functionally distinct from slightly up (pantew), which is usually combined with looking into the distance and not tied to the foraging context specifically. In this sense, a slightly upward gaze path is more similar to a horizontal gaze path than to a sharply upward turned one. In contrast, gazing down as 
marked by the verb yop begins already with a slightly downward visual path and also includes sharper gaze trajectories. There is no boundary between SHARP and NON-SHARP for DOWN as these gaze angles are not earmarked for different activities. For instance, foraging activities on the ground such as hunting for terrestrial animals or tuber digging often involve both sharp and non-sharp gaze angles. One reason for that is that the path to the ground is short so the gaze angle can be changed relatively easily (unlike in the case of a longer path). From a functional point of view, then, gazing slightly downwards and sharply down are similar. Note that even cases involving a sharply bowed headalthough associated primarily with cakip - can be described with yəp. The reason why cakip is usually preferred for scenes with a sharply bowed head is linked to the high salience of this body posture. Yэp itself is not sensitive to body posture but refers to DOWN defined in absolute terms. Occasionally, speakers employ yop as well as cakip within a single description, but since there is a strong implication regarding the visual path in cakip, it normally occurs on its own.

Summing up, the encoding of paths of vision in Maniq is shaped by multiple pressures. The locus of the main distinctions is provided by the two main spatial coordinates underlying our three-dimensional world - the horizontal and vertical planes. How this space is carved into specific categories is influenced by, on the one hand, universal constraints dictated by gravity and the mechanics of the human body, and, on the other hand, culture-specific considerations that render certain discontinuities more salient than others. It is important to point out that such fine-tuning of spatial distinctions to the parameters relevant for visual perception is possible largely because of the verbal lexicalization strategy. The sole fact that Maniq lexicalizes visual paths in verbs rather than simply applying the general spatial expressions ('satellites') to mark 
them, means the semantics of verbs of looking can be defined independently of satellites. Thus, unlike in English or Spanish, where visual paths are dictated by spatial prepositions, the partitioning of visual paths in Maniq is not constrained by satellites. I return to this again in Section 7.

\subsubsection{Object-anchored paths}

Object-anchored paths were generally not encoded in verbs expressing specific spatial relations such as 'look into', 'look across', 'look under', etc. The stimuli probing for these distinctions revealed many such paths are associated with the verb $d \varepsilon \eta$ 'to look at, to see'. This verb emerges as the main descriptor applied with visual paths which include an endpoint object.

$D \varepsilon \eta$ is semantically general and applicable in various contexts. It was the most frequent verb in both tasks. It collapses the distinction between the activity and experience (as in see vs. look, cf. Viberg 1984), covering all predicates with perceiver as the grammatical subject. Depending on context, it is thus best glossed as 'to see, to look at'. The current data show further that $d \varepsilon \eta$ is unspecified with respect to direction. In the context of direction-encoding verbs of looking discussed here, the question arises whether it could be considered a superordinate term forming a hyponymic relation with these verbs. In other words, is there a hierarchy in the vision verb lexicon?

The available evidence does not suggest a straightforward answer, though some preliminary observations can be made. If we consider $d \varepsilon \eta$ in its basic underived form, hyponymy is unlikely since $d \varepsilon \eta$ and directional verbs differ with lexical aspect. Hyponyms form a 'type-token' relationship with their superordinate terms; hence, they are expected to have all of their superordinate's features (e.g. Murphy 2003). ${ }^{11}$ The aspectual mismatch between $d \varepsilon \eta$ and the other verbs would therefore rule out hyponymy 
(see Gisborne 2010: 154 for a similar observation for English). In its default reading, $d \varepsilon \eta$ marks an accomplishment, since it refers to a telic situation, i.e. it has an inherent endpoint and is spatially bounded (although the action can extend in time). This is in line with the fact that whenever $d \varepsilon \eta$ was used in the picture naming or the translation task, it usually involved scenes which presupposed an endpoint object. Similarly, it was consistently employed for all translations of the verb see in another translation questionnaire 'Grammar of perception' (Norcliffe et al. 2010) carried out independently on a separate occasion. $D \varepsilon \eta$ also combines with the causative to derive the meaning of 'show, cause someone to see': $p i-d \varepsilon \eta$ (CAUS see). The direction-encoding verbs like balay, yəp etc., on the other hand, seem to place more emphasis on the path itself and lack inherent endpoints. This is reflected in the frequency of overt goals with different verbs. For instance, in the picture naming task, goals were overtly expressed with $d \varepsilon \eta$ more often than with any other verb (22 times, compared to 7 times for pantew, 2 times for balay, and once for cikiey and piwe). In addition, $d \varepsilon \eta$ was sometimes employed with a specific function of introducing an endpoint, as in (25) below, elicited for the DOWNINTO-bag scene. In this example the verb yop specifies the downward path, while $d \varepsilon y$ introduces the visual endpoint, which in this context can be interpreted as the inside of the object.

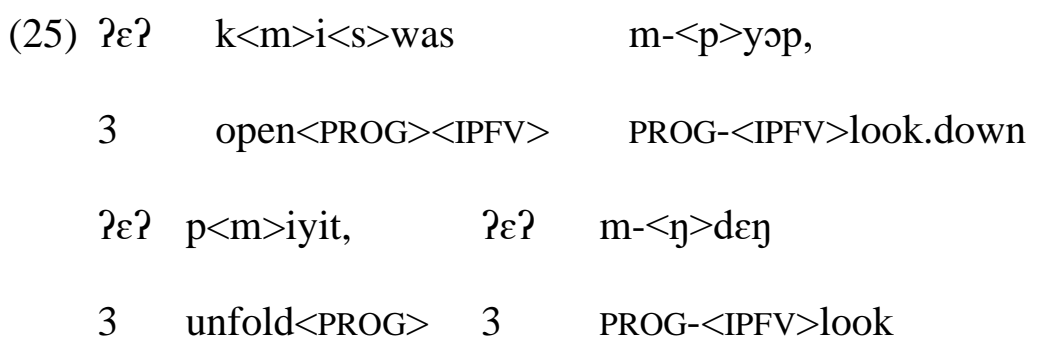

'She is opening and looking down, she's unfolding, she is looking (inside).' (\#35) 
While $d \varepsilon \eta$ in its root form seems to contrast with other verbs in telicity, this distinction can be manipulated with derivational morphology. When derived with the imperfective, the verb becomes atelic ( $d \eta-d \varepsilon \eta$ 'to be looking (around)' (IPFV-look)) since the imperfective morpheme removes spatio-temporal boundaries from the event structure (cf. Wnuk 2016a: 79-82). ${ }^{12}$ The imperfective form might therefore be a more appropriate candidate for a superordinate 'looking' term, though it would be unusual for a morphologically complex form. Further investigation targeting this issue directly is needed to explore this in depth.

\section{VISUAL PERCEPTION VS. MOTION EVENTS}

One of the central questions pursued in this article is whether the distinctions encoded across distinct sets of verbs in Maniq follow the same underlying semantic principle. The focus of the investigation, more specifically, is the encoding of path: Are visual paths and motion paths similar in Maniq? Slobin (2009) proposed that physical and visual paths are universally conceptually equated in the use of the same types of spatial expressions. This is supported by the fact that Maniq employs the same PPs with expressions of motion and vision, e.g. da? kapin 'up', hway haysl 'straight ahead', etc., as in (26) and (27).

(26) $2 \varepsilon ?$ wa da? kapin

3 go LOC up

'She is going uphill.'

(27) $? \varepsilon ? \mathrm{~d} \varepsilon \mathrm{y}$ da? kapin 
3 look LOC up

'She is looking up.'

However, path-encoding verbs - the main path-encoding strategy for both motion and vision - are not shared across the two domains. Motion verbs do not express visual paths (e.g. sa expresses downward motion but not downward gaze), and vice versa, vision verbs do not express paths of motion (e.g. yəp expresses downward gaze but not downward motion). Although the verbal forms are not shared, it is still possible the spatial distinctions underlying the verbs are, since languages often display common lexicalization patterns across distinct lexical sets (Gentner 1982). The question then is: Are the path distinctions encoded in verbs of vision and verbs of motion similar?

The basic paths mapped onto vision verbs - UP, DOWN, STRAIGHT-and-LEVEL, SIDEWAYS/BACK - are reminiscent of the basic paths mapped onto motion verbs - UP, DOWN, HORIZONTAL (cf. Table 1). Among these, the vertical directions UP and DOWN are in both cases established in the same way (i.e. by use of an absolute frame), while the horizontal directions are determined differently (i.e. relative to the absolute frame for motion, and to the egocentric frame for vision). This difference is due to the fact that motion verbs lexicalize ground objects, while the verbs of horizontal gaze lexicalize the position of the experiencer's body/eyes. An additional point of difference is the place where the boundaries between specific categories are drawn. For instance, SIDEWAYS and BACK are encoded in two distinct verbs of motion (kapoy 'to turn sideways, to change direction of motion' vs. paliy 'to turn back, to change direction of motion'), but they constitute a single category expressed with one verb of looking (cikiey 'to look 
sideways/back'). ${ }^{13}$ Despite such differences, at the global level the vertical and horizontal paths are similar.

When it comes to object-anchored paths, however, motion and vision differ significantly. In motion, there is a set of verbs encoding specific figure-ground configurations such as INTO/UNDER/THROUGH, OUT, OVER, e.g. hok 'to enter/ go under', $y \varepsilon s$ 'to exit', laykah 'to go over an obstacle' (cf. Section 3). In contrast, in vision we find a general endpoint-encoding verb $d \varepsilon \eta$. Aside from this case, no other specific verbs marking object-anchored paths of vision were found, though piwe seemed to be loosely associated with looking from behind an object. Even explicit naming of these types of paths in external phrases was rare. In addition, contrary to other languages with multiverb predicates (notably the surrounding Thai; cf. Takahashi 2000, Slobin 2009), Maniq does not express object-anchored gaze paths with motion verbs like 'exit', 'enter', etc. These differences are most likely due to the different nature of physical and fictive motion events, as fleshed out in Section 1 (cf. Slobin 2009). For instance, the lack of 'exit'-type verbs for vision and the sporadic expression of boundary crossing can be explained by the differing dynamics of visual perception and motion events.

To conclude, paths encoded across the two verb sets differ in a number of ways, but they also converge on a number of distinctions. They are anchored in the same spatial coordinates underlying three-dimensionality - the vertical and horizontal planes (Miller \& Johnson-Laird 1976, Lyons 1977). In the rest of this article, I will draw on extensive lexical evidence from the Maniq lexicon and demonstrate these spatial planes not only underlie vision and motion, but in fact provide an organizational principle pervading several areas of the Maniq lexicon.

\section{RECURRENCE OF SEMANTIC STRUCTURE IN THE LEXICON}


The lexicalization of spatial notions in verbs of motion and verbs of looking follows a general semantic principle organizing these two domains. Its essential aspect is a systematic recurrence of semantic structure across domains. To take an example of DOWN, the previous sections established that the downward path is lexicalized in two motion verbs - sa 'to descend' and wet 'to go downstream' - and the looking verb ysp 'to look down'. DOWN is thus a recurring semantic notion found independently across two distinct lexical sets: verbs of motion and visual perception. While recurrence of semantic structure is also characteristic of derived expressions (e.g. the English phrasal verbs go down and look down), here the recurring semantic material is not overtly marked (i.e. $s a$, wet and yəp do not exhibit formal similarity). Aside from verbs of motion and verbs of looking, two additional verb sets can be added to this list: positional verbs and verbs related to yam digging (digging and disposing of soil). Like verbs of motion and visual perception, these verbs lexicalize spatial notions. For instance, DOWN is encoded in the positional verb cibel 'to be upside down' and the digging verb bay 'to dig down'. Together with the motion and vision verbs, these verbs constitute a grouping of formally unrelated items sharing a common semantic notion. As I will show below, further examples of such shared patterns connecting multiple verbs from unrelated sets involve the notions UP and HORIZONTAL.

The systematic recurrence of semantic structure in these lexical sets is reminiscent of the lexico-semantic concept of SEMPLATES (Levinson \& Burenhult 2009). A semplate (a blend of 'semantic template') is a term referring to configurations consisting of 'an abstract structure or template, which is recurrently instantiated in a number of lexical sets, typically of different form classes' (Levinson \& Burenhult 2009: 153). Semplates normally involve multiple lexical subsets structuring a single well- 
defined domain, e.g. landscape or subsistence. For example, Levinson and Burenhult (2009: 159-161) describe the 'landscape semplate' in Jahai (spoken in Malaysia), in which the same set of spatial oppositions is mapped onto different lexical sets within the landscape domain: motion verbs, locative verbs, place names, and metaphorical nouns denoting landscape features. The notion of a semplate is special in that it captures both the geometric structure of the semantic oppositions within lexical sets as well as the higher-order analogical relations between lexical sets.

The configuration of spatial oppositions in Maniq is semplate-like, in the sense that it is associated with an abstract semantic structure. However, since it is not restricted to one well-defined domain, but associated with several unrelated domains (motion, vision, etc.), it departs from prototypical semplates. Irrespective of this, there is a striking similarity between semplates and this configuration as both rely on the same general idea, i.e. they provide a semantic organizational principle structuring multiple lexical sets.

The Maniq semplate-like structure encodes the spatial notions of UP, DOWN, and HORIZONTAL. Figure 12 provides a summary of the relevant verbal subsets. Depending on the verb, the HORIZONTAL category can be associated with horizontality in general (as in tiek 'to lie (be positioned horizontally)') or express a specific type of horizontal category relevant for a particular domain (as in $c \varepsilon n$ 'to move along the top of an object' for the domain of motion on trees, or small obstacles). All but two items in the semplate-like structure are monomorphemic and formally unrelatable, which is a common feature of categories making up semplates but not an absolute rule since lexically overt multimorphemic forms are also attested in semplates (cf. Levinson \& Burenhult 2009). The two exceptions include the complex predicates: kac huyu? 'to 
dispose of soil by throwing it up' and kac scy 'to dispose of soil by throwing it to the side', where the shared verb kac indicates the activity of scooping up soil while the second verb determines the direction (though neither *huyu? nor ${ }^{*} s c y$ seem to ever occur on their own and speakers reject such forms).

While the spatial coordinates underlying this structure are common for all lexical sets, the exact category boundaries are domain-specific. For instance, UP and DOWN are somewhat different for motion verbs from different sets, e.g. milder for 'ascend-hill' verb and steeper for 'ascend-tree' verb. Similarly, HORIZONTAL is defined with respect to different reference points depending on the verb set, i.e. landscape features for motion verbs, body for vision and locative verbs, and tuber anatomy for yam-digging verbs.

Semplates are typically manifest across different form classes. There is some preliminary evidence the spatial semplate-like structure in Maniq also extends into other form classes, which would suggest the pattern is not restricted to verbs, but applies more generally. For instance, horizontality and verticality is mapped onto nouns indicating different tuber parts, i.e. jalie? 'main tuber (growing vertically)', lapieh 'side tuber (growing horizontally)'. However, since the present focus is on verbs, other form classes are not explored further here.

<Insert Figure 12 about here>

\section{CONCLUSIONS}

The evidence reviewed in this article demonstrates visual paths are encoded in verb roots in Maniq. This is noteworthy since it has been observed before that visual paths 
are resistant to being lexicalized in verbs (e.g. Slobin 2009). This article is the first extensive report of the verb-framing strategy for looking events. Although detailed accounts of similar systems are missing, we know this strategy is not exclusive to Maniq as there are some previous reports of languages with looking verbs marked for direction, e.g. Toba, spoken in Argentina (Klein 1981), and Kayardild, spoken in Australia (Evans \& Wilkins 2000). Together with these earlier sources, the Maniq data show languages need not lose their verb-framed nature in descriptions of visual perception events. The Maniq case is thus testimony to the fact visual paths are not generally barred from being encoded in verbal roots. This has important implications for the typology of vision verbs, as it suggests the 'typological split' experienced by the verb-framed languages such as Spanish is not a universal phenomenon. In addition to these theoretical implications, the study makes a methodological contribution by identifying relevant semantic parameters and offering example methods for investigating such verbs.

The present findings suggest visual paths may be coded in verbs, but this is not true of all types of visual paths in Maniq. For example, no special verbs exist for paths with boundary-crossing such as into and out of. This might reflect a common trend since among the infrequent mentions of path-encoding verbs of looking in the literature, paths without inherent boundaries dominate, e.g. walmurrija 'look up in the sky', warayija 'look back', rimarutha 'look eastwards at' in Kayardild (Evans \& Wilkins 2000: 554), $s a: t$ 'to look up (at something moving)', la 'look ahead (in direction of something nearby)' in Toba (Klein 1981: 234). However, examples which involve boundarycrossing are not absent, e.g. Ie 'look outward', wa 'look for, search (look inward)' (also in Toba). Based on this rather small sample, it appears verbs with boundary-crossing 
paths might indeed be rare, but far more attention needs to be devoted to documentation of verbs of looking cross-linguistically before it becomes clear how robust this tendency is.

The specific types of looking events lexicalized in Maniq verbs are culturally salient activities implying specific scenarios. The cultural salience as well as Maniq's consistent preference for lexicalizing spatial notions in verb roots are the key factors in the existence of these verbs in Maniq. What the Maniq data show most clearly is that the lexicalization of visual paths in verbs rather than satellites has a non-trivial impact on their semantics. As elucidated in the previous sections, the lexicalization patterns within paths of vision reflect a complex interplay of pressures - vision verbs are synchronized with universal constraints and tailored to culture-specific requirements (cf. Evans \& Levinson 2009, Majid 2015). The exact meanings of verbs of looking are thus shaped by earth-based verticality, bodily mechanics, the environment, and cultural scenarios of which looking is a salient part. This vision-specific fine-tuning of the spatial notions relevant for paths would not have been possible if the preferred strategy was to encode path in satellites. In such a scenario, it is probable the meaning of the visual paths would be dictated by the general meaning of the satellites. What the verbencoding strategy affords a language is a freedom to adjust the fine semantic details of its spatial categories according to a domain-specific logic.

Different domains encoding spatial information in verbs display fine-level differences as to how spatial distinctions are defined (e.g. HORIZONTAL locked to body vs. landscape vs. tuber axes). At the global level, however, spatial notions are similar across domains. This is illustrated by the spatial semplate-like structure, where similar spatial notions are lexicalized in at least four otherwise unrelated semantic fields. With 
striking systematicity, Maniq organizes its verbs of looking, verbs of motion, positionals, and verbs related to yam digging around the same spatial notions of UP, DOWN and HORIZONTAL. Thanks to domain-specific fine-tuning of these notions, spatial information in verbs is more precise than, for instance, spatial information encoded in prepositions, which have a more general range of applicability. This implies that knowing how to use these verbs correctly requires from the speaker not just general spatial knowledge, but the SPECIFIC ORGANIZATION of spatial knowledge in a particular domain. The semantic fields which partake in the Maniq spatial semplate-like structure relate to culturally salient notions with the relevant domains, often linked to the indigenous expertise of the speakers, and central in their way of life. This in fact seems to be a characteristic of semplates found in other languages too, e.g. Tzeltal (Mexico), Yélî Dnye (Papua New Guinea), and Jahai (Malaysia).

Vision verbs and other lexical sets making up this semantic configuration are most notable because they illustrate systematicity in the organization of information. In general, verbs are believed to have considerable freedom in what event aspects they lexicalize (Gentner 1982, Talmy 1985). This is reflected in substantial cross-linguistic variation of verb meaning (e.g. Bowerman et al. 2004, Levinson \& Wilkins 2006, Majid, Boster \& Bowerman 2008, Malt et al. 2014). When compared to concrete nouns, verbs show a 'more variable mapping from concepts to words' (Gentner 1982: 47), and have been hypothesized as 'likely (...) the most cross-linguistically variable part of a language's vocabulary in terms of denotation' (Evans 2011: 189, though see Thompson, Roberts \& Lupyan 2020 for observations on similarly high variability in conjunctions and prepositions). Within a particular language, however, there is less variability since the packaging of information within verbs may be ordered according to an underlying 
pattern. As the Maniq data show, these patterns need not be overt, but can be encoded in non-transparent verb forms. Thus, even though the various verbs are not formally related to one another, the meanings encoded by them show correspondences. This kind of systematicity is less noticeable, yet - similar to the overt forms of systematicity (Dingemanse et al. 2015) - it is of high significance, playing a supporting role in language acquisition (Choi \& Bowerman 1991; Brown 2001; Gentner 1982; Slobin 2001) and acting as a shaping force in lexicalization.

\section{APPENDIX 1}

1. The boy looked up the tree in search of fruit. เด็กชายมอง(ขึ้น)บนต้นไม้เพื่อหาผลไม้

2. The man looked up the tree in search of leaf monkeys. ผู้ชายมอง(ขึ้น)บนต้นไม้เพื่อหาลิง

3. The young macaque looked up at his mother getting bananas above in the tree. ชะนีมอง(ขึ้น)ที่แม่ที่กำลังเก็บกล้วยบนต้น

4. The man looked up (with his eyes) without moving his head. ผู้ชายกลอกสายตาขึ้น

5. The men were moving through a dense forest carefully looking down to avoid stepping on snakes.

กลุ่มผู้ชายเดินผ่านป่ารกอย่างระมัดระวัง มองข้างล่างหลีกเลี่ยงการเหยียบงู

6 . The woman sitting at the top of the stairs looked down at her child playing on the ground.

ผู้หญิงที่นั่งอยู่บนบันไดมองลงดูลูกที่เล่นอยู่บนพื้น

7. The leaf monkey looked down at the hunter when it heard him walking.

ลิงมองลงไปที่นายพรานเมื่อมันได้ย้นเสียงเขาเดิน

8. The boy looked down into the water searching for fish.

เด็กชายมองไปในน้ำเพื่อหาปลา

9. The man looked down (with his eyes) without moving his head.

ผู้ชายกลอกสายตาลง

10. The hunters were walking and looking sideways from time to time.

นายพรานเดินและมองข้างทางเป็นระยะ

11. The couple was sitting quietly side by side looking into the distance. When the man started speaking, (...)

ชายหญิงคู่หนึ่งนั่งเงียบๆข้างๆกันมองออกไป เมื่อผู้ชายเริ่มพูด

12. a) (...) the woman turned her head sideways and looked at him. ผู้หญิงหันหน้าไปมองเขา

13. b) (...) the woman looked sideways (with her eyes) without moving the head. ผู้หญิงกลอกสายตาไปด้านข้าง

14. The little boy detached from the group and soon realized he was lost. He began looking around him in all directions to find his way back.

เด็กชายพลัดหลงกับกลุ่ม เขาเริ่มมองไปรอบๆตัวเพื่อหาทางกลับ 
15. The bird was looking around in all directions in search of food. นกมองไปรอบๆตัวเพื่อหาอาหาร

16. The group was walking in line through a narrow path. The man in the lead looked over his shoulder from time to time to see if the rest could keep up with his pace. After a while he stopped, turned back (with his whole body) and looked again to check if everyone was there.

กลื่มคนเดินเป็นแถวผ่านทางแคบ ผู้นำหันหน้าไปมองเป็นระยะเพื่อดูว่าทุกคนตามเขาทัน สักพักเขาหยุดเอี้ยวตัวไปมองอีกครั้งเพื่อดูว่า ทุกคนอยู่ครบ

17. The deer looked back when it heard a noise coming from behind. กวางหันหลังไปมองเมื่อได้ยินเสียงจากข้างหลัง

18. The woman looked into the basket to see if she had many tubers. ผู้หญิงมองในตะกร้าเพื่อดูว่ามีหัวมันมากหรือยัง

19. Standing by the door he peered into the house to check if anyone was home. เขายืนอยู่ที่ประตูมองเข้าไปในบ้านเพื่อดูว่ามีใครอยู่หรือเปล่า

20. The man looked inside his blowpipe to see if it was clean. ผู้ชายมองเข้าไปในลำกล้องเพื่อดู่ามันสะอาดหรือยัง

21. The badger looked inside its den.

หมูดินมองเข้าไปในหลุม

22. The man looked through the gap in the thicket and saw a group of people.

ผู้ชายมองผ่านช่องระหว่างพุ่มไม้และเห็นกลุ่มคน

23. The tiger looked at a deer through the sparse vegetation.

เสือมองกวางผ่านช่องระหว่างพุ่มไม

24. When she heard the men coming back from the forest, she put her head out and looked out from the house.

เมื่อเธอได้ยินเสียงคนกลับมาจากป่า เธอชะโงกหน้าออกจากบ้านไปมอง

25. The rat looked out from the burrow in the ground.

หนูมองออกมากจากรู

26. I couldn't find my machete so I looked under the bed to check if it was there.

ผมหาพร้าไม่เจอ จึงไปดูใต้เตียงว่ามีหรือเปล่า

27. The dog looked under the bed to see if he could find remnants of food. หมามองหาเศษอาหารใต้เตียง

28. He looked over a fallen tree trunk to see what was on the other side. เขามองข้ามท่อนไม้เพื่อดูว่ามีอะไรอีกศั่ง

29. The deer looked over the bushes checking if there was no enemy there. กวางมองข้ามพุ่มไม้เพื่อดูว่าไม่มีศัตรู

30. He looked across the river and saw a 'langu' palm on the other side. เขามองข้ามแม่น้ำและเห็นต้นปาล์มอีกฝั่ง

31. The tiger looked across the road and saw some deer on the other side.

เสือมองข้ามถนนและเห็นกวางอีกฝั่ง

32. The man looked along the river in search of a place for taking a bath.

ผู้ชายมองไปตามแม่น้ำเพื่อหาที่อาบน้ำ

33. The macaque looked along the river in search of a place where it could reach the water.

ชะนีมองไปตามแม่น้ำเพื่อหาที่กินน้ำ

34. The small boy was playing with a blowpipe. He looked through the shaft into his house.

เด็กชายเล่นลำกล้อง เขามองเข้าไปบ้านผ่านช่องลำกล้อง

35. The man looked down through the (holes in the) floor at the people under his house. ผู้ชายมองดูคนใต้ถุนบ้านผ่านช่องบนพื้นบ้าน

36. He looked up into a tree hole. 
เขามองขึ้นไปดูรูบนต้นไม้

37. The woman looked over the head of her child out of the house.

ผู้หญิงมองข้ามหัวลูกออกไปนอกบ้าน

38. The man looked out through the door, past the houses, into the forest.

ผู้ชายมองผ่านประตู้านออกไปในป่าผ่านบ้านอีกหลัง

39. He is lying on the back looking at the sky:

เขานอนหงายมองท้องฟ้า

40. He is lying on the back looking at a child lying beside him เขานอนหงายมองเด็กที่นอนข้างๆ

41. He is lying on the back looking down from the hut

เขานอนหงายมองลงมาจากบ้าน

42. He is lying on the belly looking down under the house

เขานอนคว่ำมองลงมาจากบ้าน

43. He is lying on the belly looking up the sky

เขานอนคว่ำมองท้องฟ้า

44. He is lying on the belly looking at a child lying next to him เขานอนคว่ำมองเด็กที่นอนข้างๆ

45. He is lying on the side looking down under the house.

เขานอนตะแคง มองลงมาจากบ้าน

46. He is lying on the side looking up the sky

เขานอนตะแคงมองท้องฟ้า

47. He is lying on the side looking at a child lying next to him.

เขานอนตะแคงมองเด็กที่นอนข้างๆ

48. He looked upstream.

เขามองไปทางต้นน้ำ

49. He looked downstream.

เขามองไปทางที่น้ำไหลไป

50. He looked uphill.

เขามองขึ้นไปบนภูเขา

51. He looked downhill.

เขามองลงมาจากภูเขา

52. He looked east.

เขามองทิศตะวันออก

53. He looked west.

เขามองทิศตะวันตก

54. The woman looked through the water in the river and saw red stones at the bottom. ผู้หญิงมองผ่านน้ำในแม่น้ำและเห็นก้อนหินสีแดง

55. The woman looked at the water in the river.

ผู้หญิงมองน้ำในแม่น้ำ

56. The woman looked at the fire.

ผู้หญิงมองไฟ

57. The woman looked: at the smoke / through the smoke.

ผู้หญิงมองควัน/ผ่านควัน

58. The woman looked at the fog / through the fog.

ผู้หญิงมองหมอก/ผ่านหมอก

59. The woman looked at the eyes of her child.

ผู้หญิงมองตาลูก 
APPENDIX 2

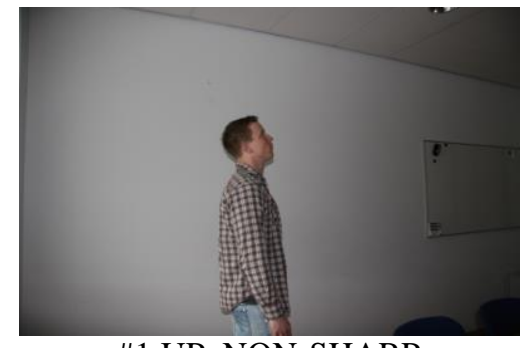

\#1 UP_NON-SHARP

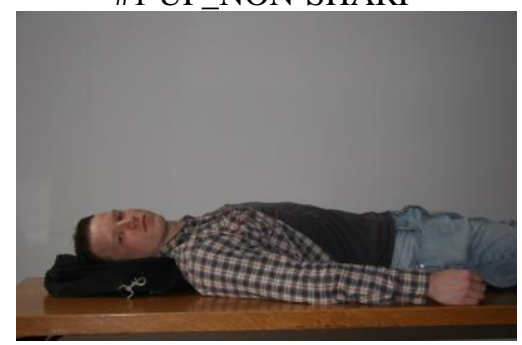

\#4 RIGHT_lying_on_back

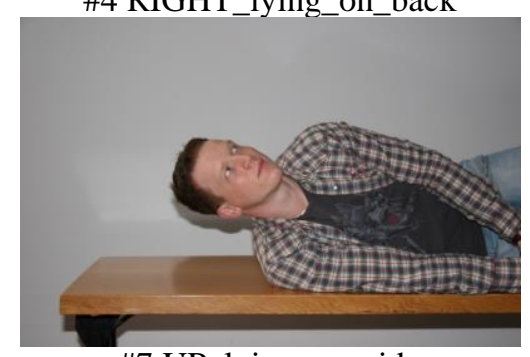

\#7 UP_lying_on_side

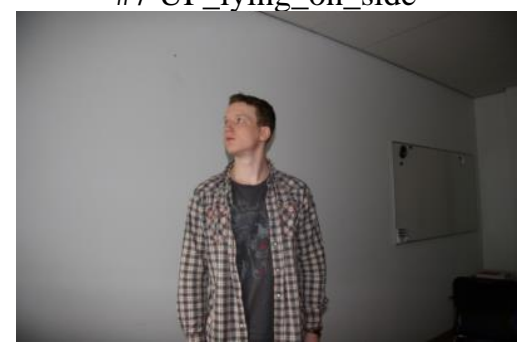

\#10 UP_and_RIGHT

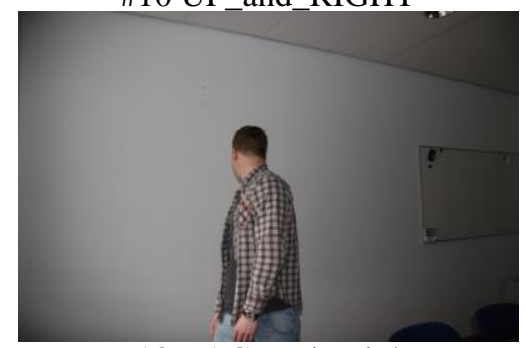

\#13 BACK_via_right

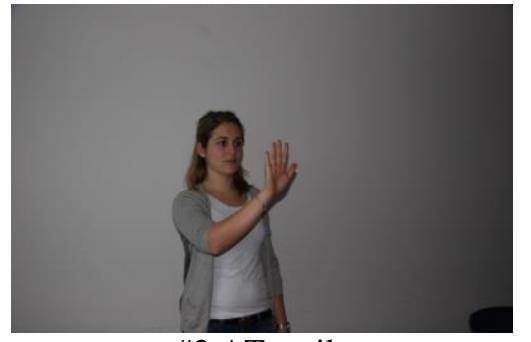

\#2 AT_nails

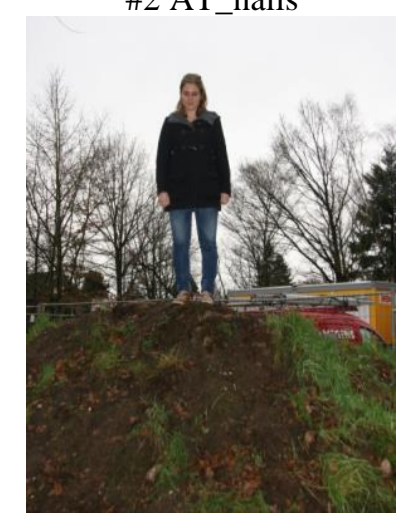

\#5 DOWN_from_top_of_mound

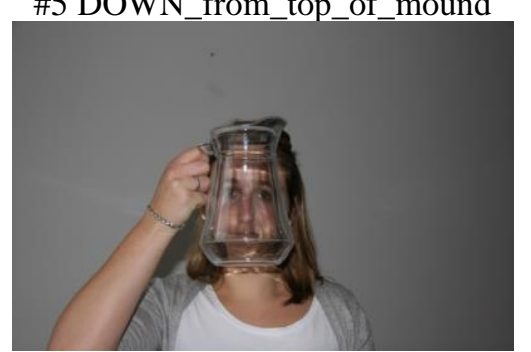

\#8 THROUGH_glass

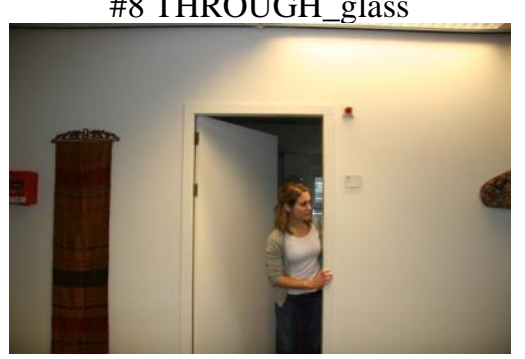

\#11 OUT_of_room

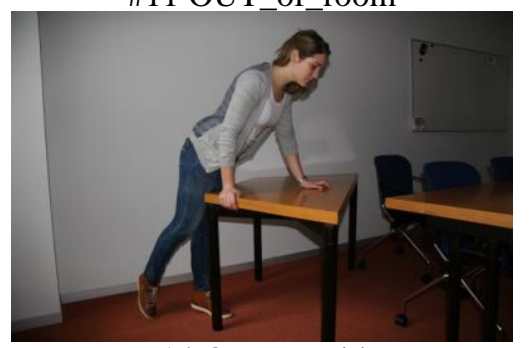

\#14 OVER_table

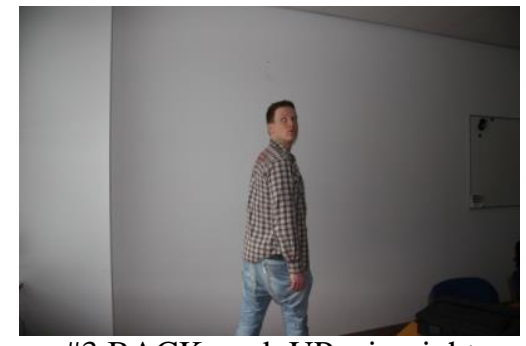

\#3 BACK_and_UP_via_right

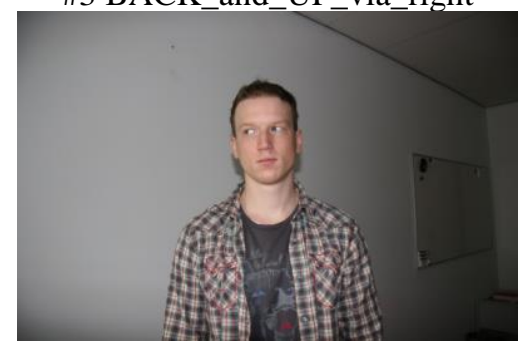

\#6 RIGHT_just_eyes

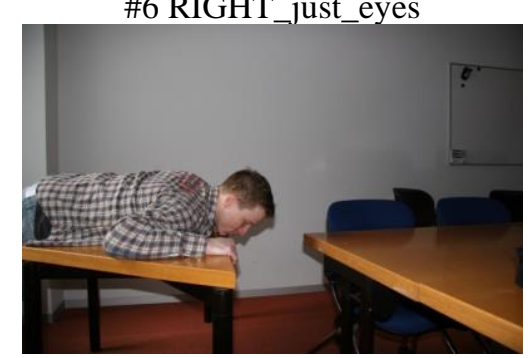

\#9 DOWN_lying_on_belly

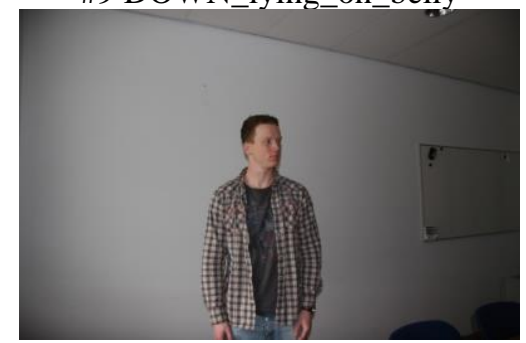

\#12 LEFT_NON-SHARP

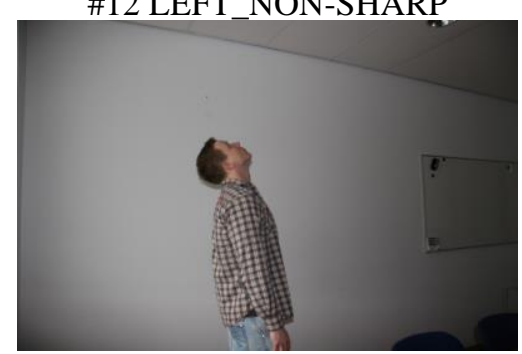

\#15 UP_SHARP 


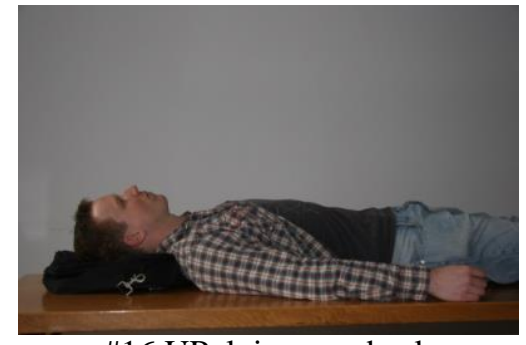

\#16 UP_lying_on_back

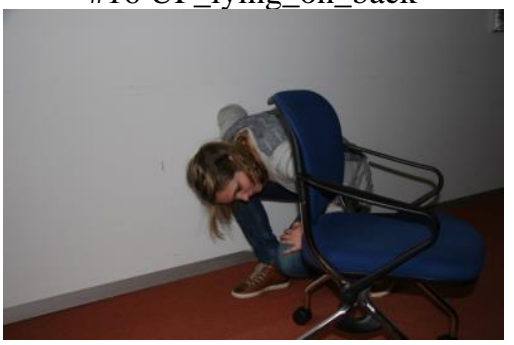

\#19 UNDER chair

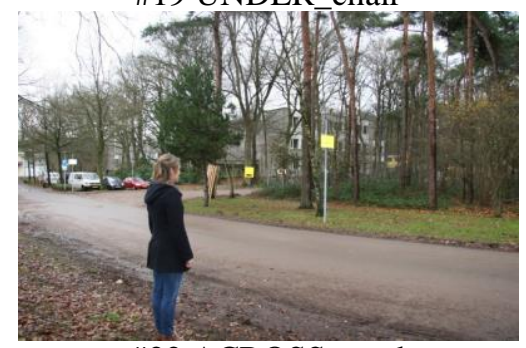

\#22 ACROSS_road

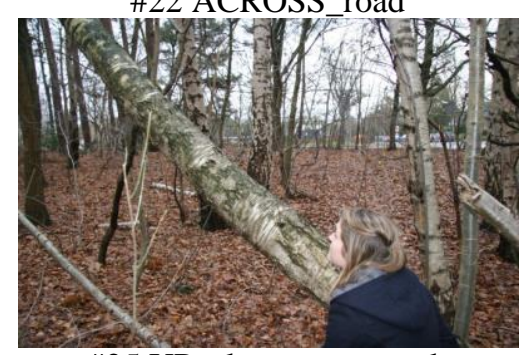

\#25 UP_along_tree_trunk

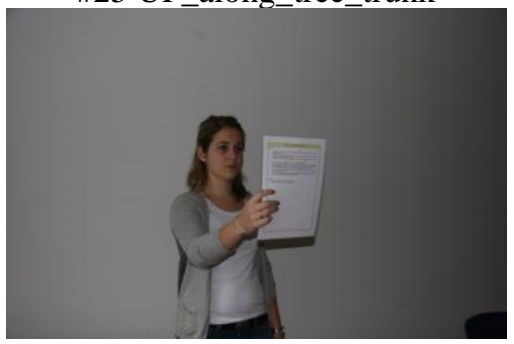

\#28 AT_paper

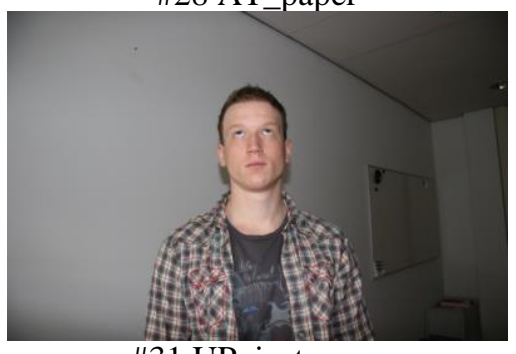

\#31 UP_just_eyes

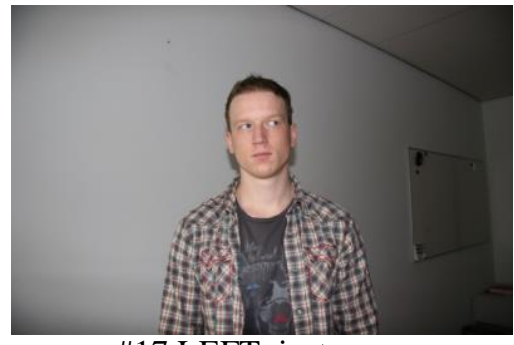

\#17 LEFT_just_eyes

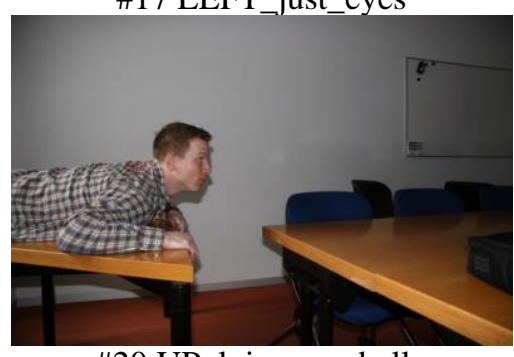

\#20 UP lying on belly

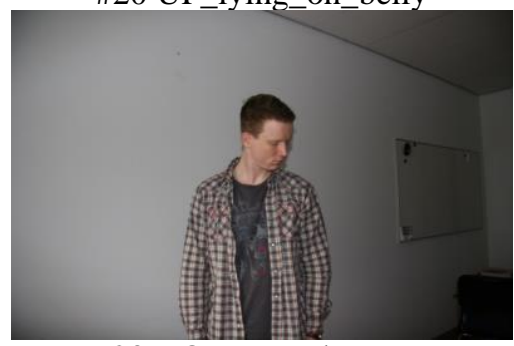

\#23 DOWN and LEFT

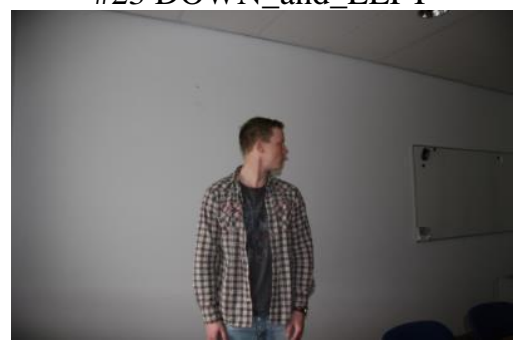

\#26 LEFT_SHARP

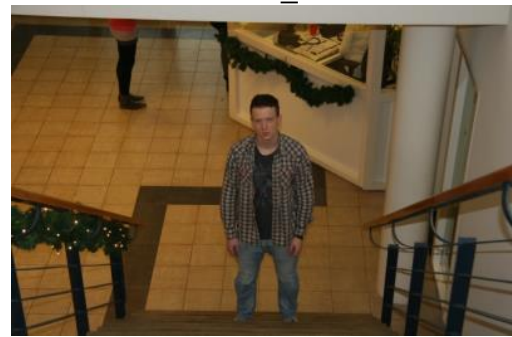

\#29 UP from bottom_of stairs

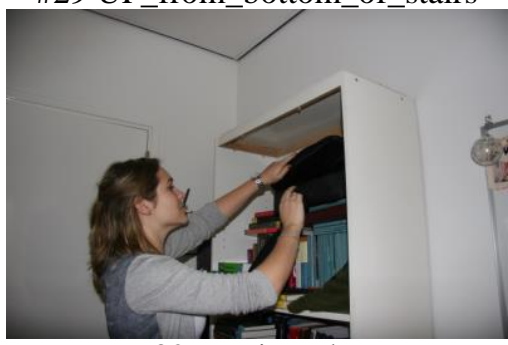

\#32 UP_into_bag

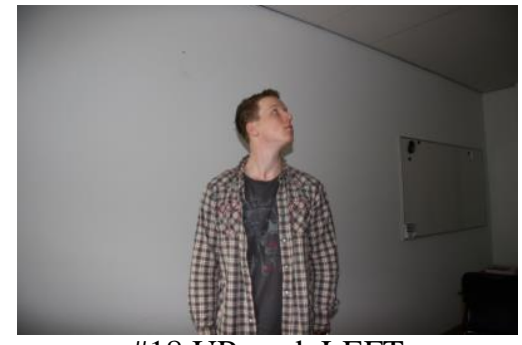

\#18 UP_and_LEFT

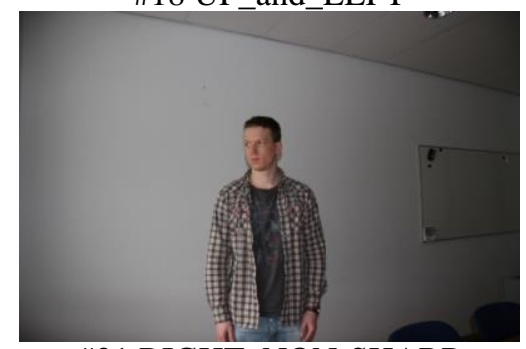

\#21 RIGHT_NON-SHARP

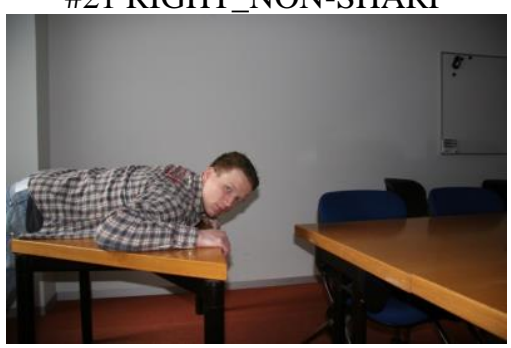

\#24 RIGHT_lying_on_belly

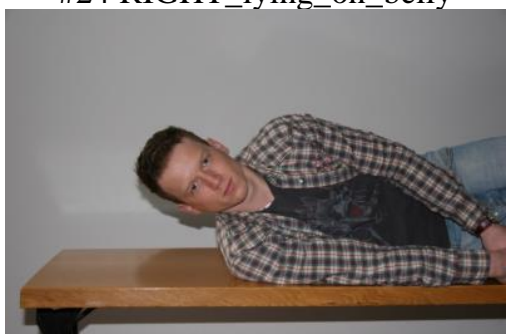

\#27 STRAIGHT_lying_on_side

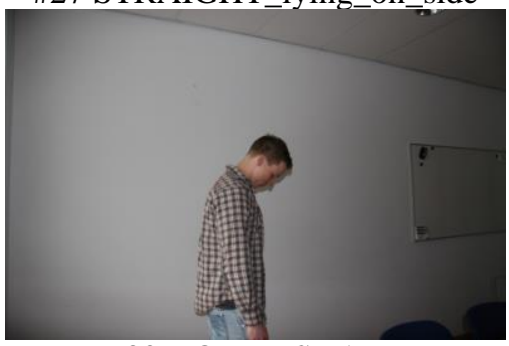

\#30 DOWN SHARP

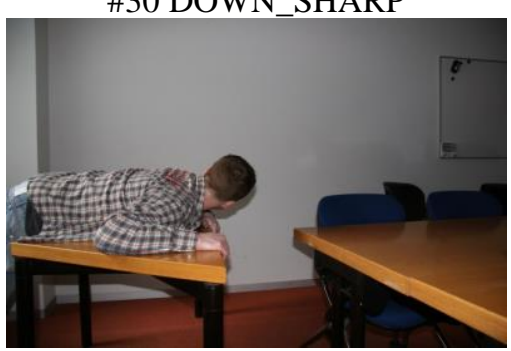

\#33 LEFT_lying_on_belly 


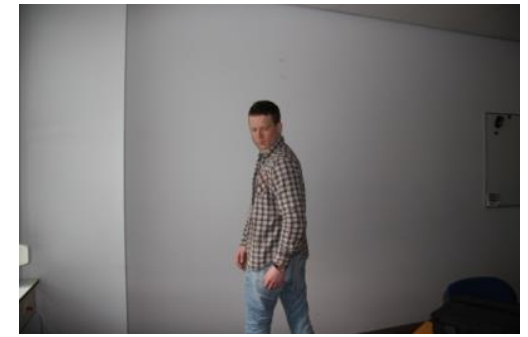

\#34 BACK and DOWN via left

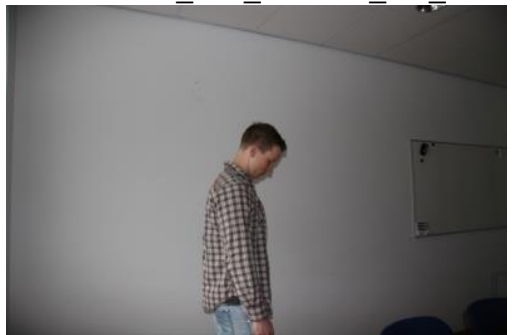

\#37 DOWN_NON-SHARP

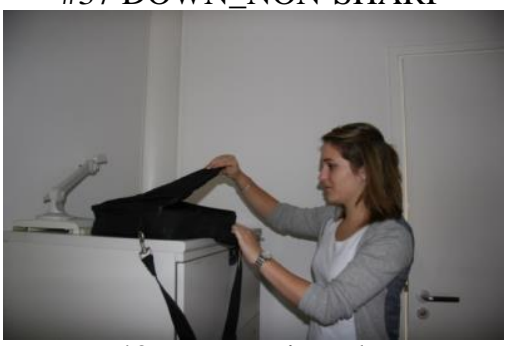

\#40 LEVEL_into_bag

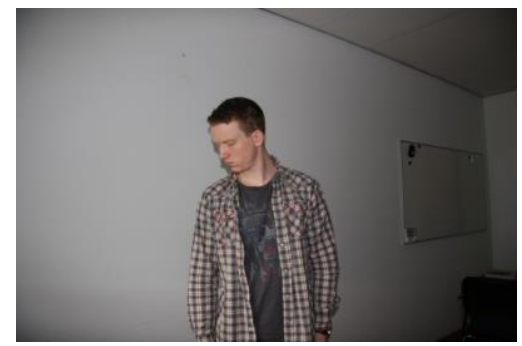

\#43 DOWN_and_RIGHT

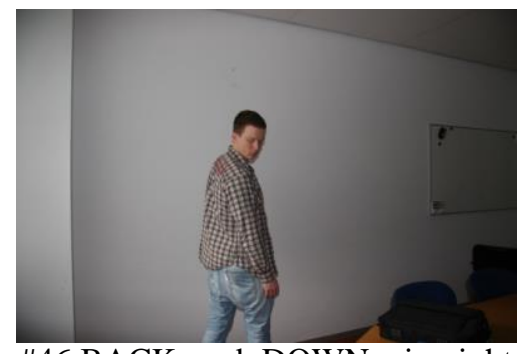

\#46 BACK_and_DOWN_via_right

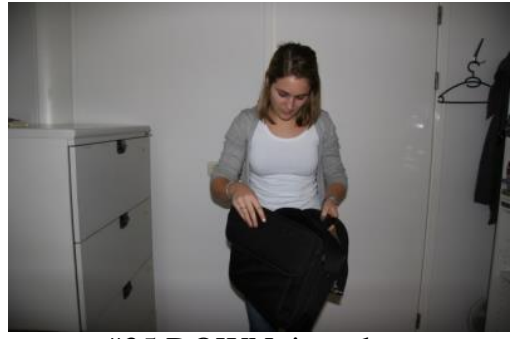

\#35 DOWN_into_bag

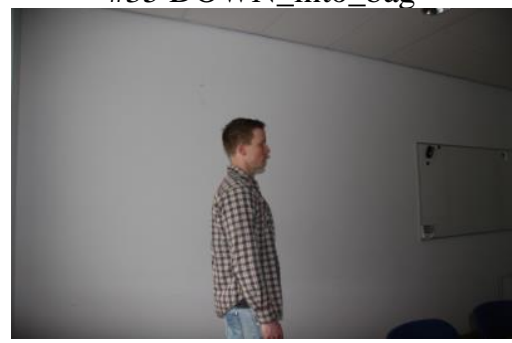

\#38 LEVEL_and_STRAIGHT

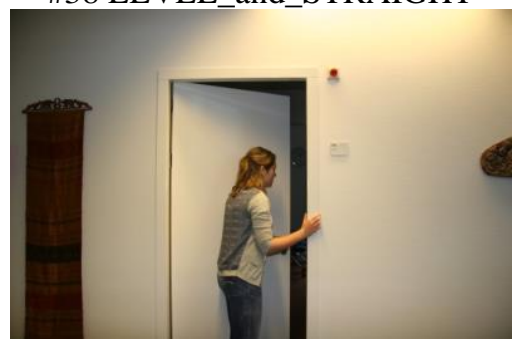

\#41 INTO room

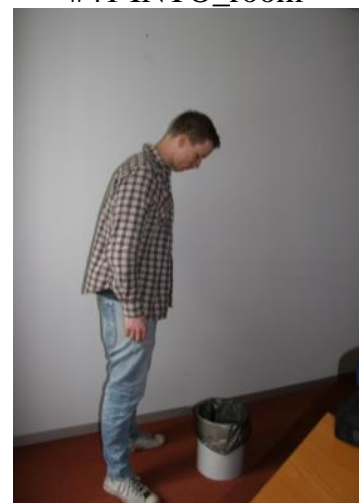

\#44 INTO_bin_straight

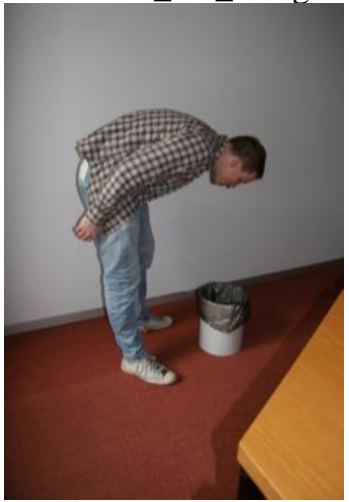

\#47 INTO_bin_leaning

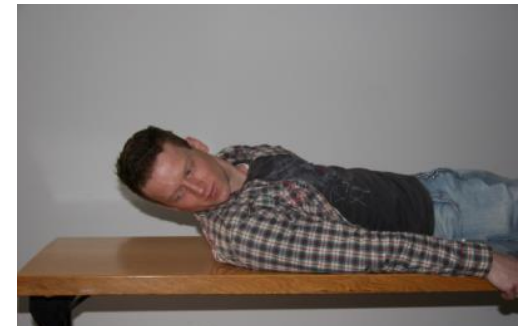

\#36 DOWN lying_on BACK

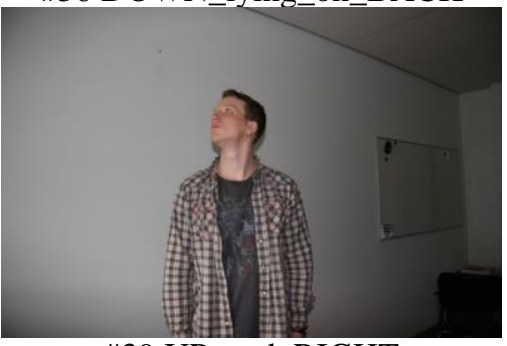

\#39 UP and RIGHT

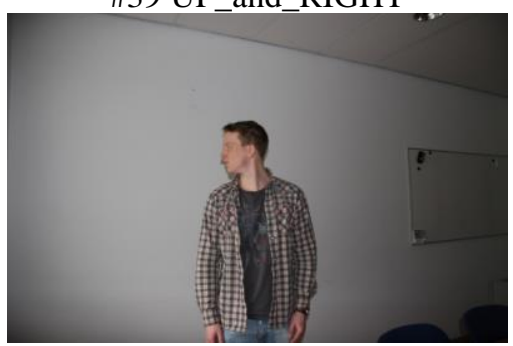

\#42 RIGHT SHARP

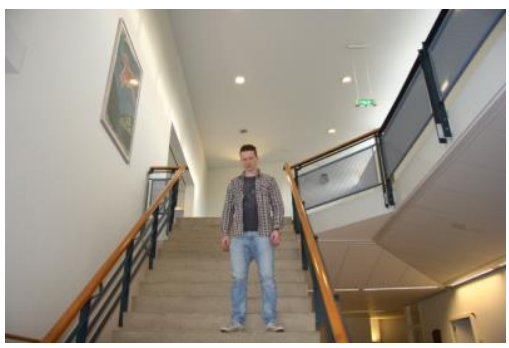

\#45 DOWN_from_stairs

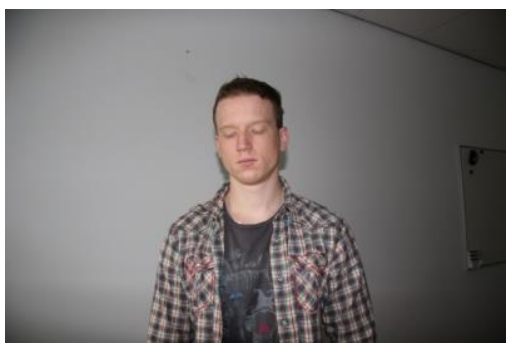

\#48 DOWN_just_eyes 


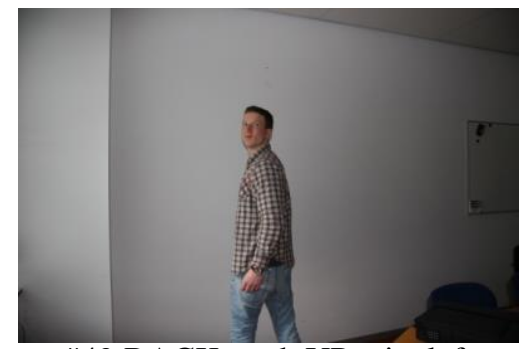

\#49 BACK_and_UP_via_left

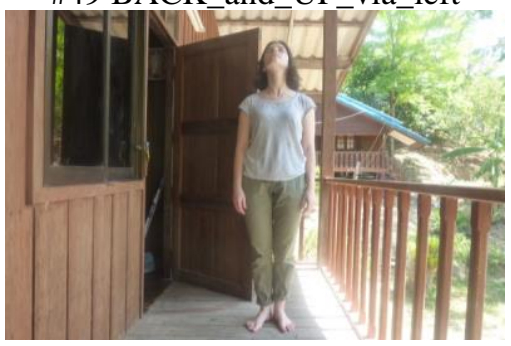

\#52 UP_eyes_closed

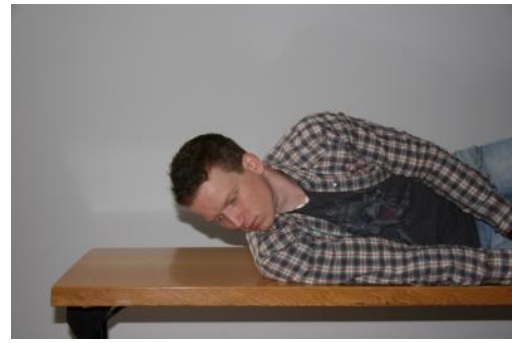

\#50 DOWN lying on side

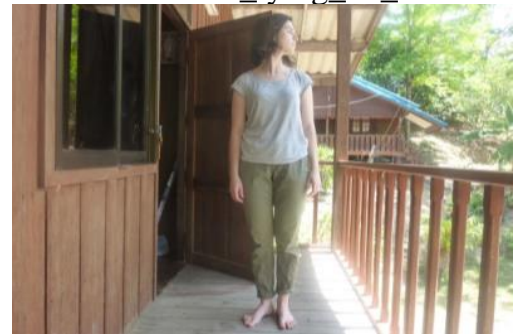

\#53 LEFT_eyes_closed

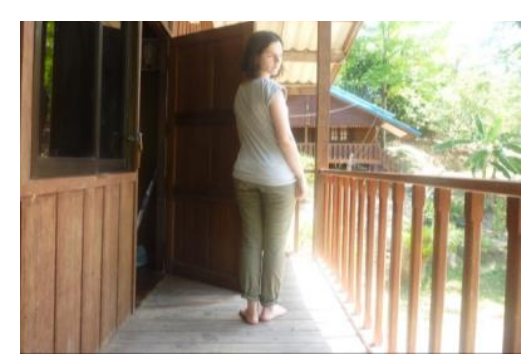

\#51 BACK_eyes_closed

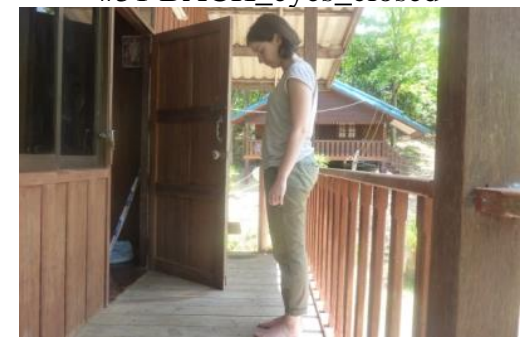

\#54 DOWN_eyes_closed 


\section{REFERENCES}

Beavers, John \& Andrew Koontz-Garboden. 2012. Manner and Result in the Roots of Verbal Meaning. Linguistic Inquiry 43(3), 331-369. doi:10.1162/LING_a_00093.

Beavers, John, Beth Levin \& Shiao Wei Tham. 2010. The typology of motion expressions revisited. Journal of Linguistics 46(2), 331-377. doi:10.1017/S0022226709990272.

Bowerman, Melissa, Marianne Gullberg, Asifa Majid \& Bhuvana Narasimhan. 2004. Put project: The cross-linguistic encoding of placement events. In Asifa Majid (ed.), Field manual, vol. 9, 10-24. Nijmegen: Max Planck Institute for Psycholinguistics.

Brown, Penelope. 2001. Learning to talk about motion UP and DOWN in Tzeltal: Is there a language-specific bias for verb learning? In Melissa Bowerman \& Stephen C. Levinson (eds.), Language acquisition and conceptual development, 512-543. Cambridge: Cambridge University Press.

Brown, Penelope \& Stephen C. Levinson. 1993. 'Uphill' and 'downhill' in Tzeltal. Journal of Linguistic Anthropology 3(1), 46-74. doi:10.1525/jlin.1993.3.1.46.

Burenhult, Niclas. 2008. Streams of words: Hydrological lexicon in Jahai. Language Sciences 30(2-3), 182-199. doi:10.1016/j.langsci.2006.12.005.

Burenhult, Niclas \& Nicole Kruspe. 2016. The language of eating and drinking: A window on Orang Asli meaning-making. In Kirk Endicott (ed.), Malaysia's original people: Past, present and future of the Orang Asli, 175-199. Singapore: National University of Singapore Press. 
Carlson-Radvansky, Laura A. \& David E. Irwin. 1993. Frames of reference in vision and language: Where is above? Cognition 46(3), 223-244. doi:10.1016/00100277(93)90011-J.

Choi, Soonja \& Melissa Bowerman. 1991. Learning to express motion events in English and Korean: The influence of language-specific lexicalization patterns. Cognition 41(1), 83-121.

Cifuentes-Férez, Paula. 2014. A closer look at Paths of vision, Manner of vision and their translation from English into Spanish. Languages in Contrast 14(2), 214250.

Coventry, Kenny R., Richard Carmichael \& Simon C. Garrod. 1994. Spatial prepositions, object-specific function, and task requirements. Journal of Semantics 11(4). Oxford University Press, 289-309.

Dingemanse, Mark, Damián E. Blasi, Gary Lupyan, Morten H. Christiansen \& Padraic Monaghan. 2015. Arbitrariness, iconicity, and systematicity in language. Trends in Cognitive Sciences 19(10), 603-615. doi:10.1016/j.tics.2015.07.013.

Evans, Nicholas. 2011. Anything can happen: The verb lexicon and interdisciplinary fieldwork. In Nick Thieberger (ed.), The Oxford handbook of linguistic fieldwork (Oxford Handbooks in Linguistics), 183-208. Oxford: Oxford University Press.

Evans, Nicholas \& Stephen C. Levinson. 2009. The myth of language universals: Language diversity and its importance for cognitive science. Behavioral and Brain Sciences 32(05), 429-448. doi:10.1017/S0140525X0999094X.

Evans, Nicholas \& David Wilkins. 2000. In the mind's ear: The semantic extensions of perception verbs in Australian languages. Language 73(3), 546-592. 
Feist, Michele I. 2008. Space between languages. Cognitive science 32(7). Wiley Online Library, 1177-1199.

Gentner, Dedre. 1982. Why nouns are learned before verbs: Linguistic relativity versus natural partitioning. In Stan A. Kuczaj (ed.), Language development: Vol. 2. Language, thought, and culture, 301-334. Hillsdale, NJ: Lawrence Erlbaum Associates.

Gentner, Dedre \& Lera Boroditsky. 2001. Individuation, relativity, and early word learning. In Melissa Bowerman \& Stephen C. Levinson (eds.), Language acquisition and conceptual development (Language, Culture and Cognition 3). Cambridge: Cambridge University Press.

Gisborne, Nikolas. 2010. The event structure of perception verbs (Oxford Linguistics). Oxford: Oxford University Press.

González Fernández, María Jesús. 1997. Sobre la motivación semántica de las expresiones pleonásticas de movimiento: Subir, bajar abajo, entrar adentro y salir afuera. In Concepción Company Company (ed.), Cambios diacrónicos en el español, 123-141. México: Universidad Autónoma de México.

Gruber, Jeffrey S. 1967. Look and see. Language 43(4), 937-947. doi:10.2307/411974. Jackendoff, Ray. 1983. Semantics and cognition (Current Studies in Linguistics Series 8). Cambridge, MA: MIT Press.

Jackendoff, Ray. 1985. Multiple subcategorization and the $\vartheta$-criterion: The case of climb. Natural Language \& Linguistic Theory 3(3). Springer, 271-295.

Klein, Harriet E. Manelis. 1981. Location and direction in Toba: Verbal morphology. International Journal of American Linguistics 47(3), 227-235. 
Kraft, Thomas S., Vivek V. Venkataraman \& Nathaniel J. Dominy. 2014. A natural history of human tree climbing. Journal of Human Evolution 71, 105-118. doi:10.1016/j.jhevol.2014.02.002.

Kruspe, Nicole. 2010. A dictionary of Mah Meri as spoken at Bukit Bangkong (Oceanic Linguistics Special Publication 36). Honolulu: University of Hawaii Press.

Kruspe, Nicole, Niclas Burenhult \& Ewelina Wnuk. 2015. Northern Aslian. In Paul Sidwell \& Mathias Jenny (eds.), Handbook of the Austroasiatic languages, 419474. Leiden: Brill.

Levelt, Willem J. M. 1984. Some perceptual limitations on talking about space. In Andrea J. Van Doorn, Wim A. Van de Grind \& Jan J. Koenderink (eds.), Limits in perception, 323-358. Utrecht: VNU Science Press.

Levinson, Stephen C. 2001. Motion verb stimulus, version 2. In Stephen C. Levinson \& N. J. Enfield (eds.), Manual for the field season 2001, 9-13. Nijmegen: Max Planck Institute for Psycholinguistics.

Levinson, Stephen C. 2003. Space in language and cognition: Explorations in cognitive diversity (Language, Culture, and Cognition 5). Cambridge: Cambridge University Press.

Levinson, Stephen C. \& Niclas Burenhult. 2009. Semplates: A new concept in lexical semantics? Language 85(1), 153-174. doi:10.1353/lan.0.0090.

Levinson, Stephen C., Sergio Meira \& The Language and Cognition Group. 2003. 'Natural concepts' in the spatial topological domain - adpositional meanings in crosslinguistic perspective: An exercise in semantic typology. Language 79(3), $485-516$. 
Levinson, Stephen C. \& David Wilkins (eds.). 2006. Grammars of space: Explorations in cognitive diversity (Language, Culture, and Cognition 6). Cambridge: Cambridge University Press.

Lyons, John. 1977. Semantics. Cambridge: Cambridge University Press.

Majid, Asifa. 2015. Comparing lexicons cross-linguistically. In John R. Taylor (ed.), The Oxford handbook of the word, 364-379. Oxford: Oxford University Press. doi:10.1093/oxfordhb/9780199641604.013.020.

Majid, Asifa, James S. Boster \& Melissa Bowerman. 2008. The cross-linguistic categorization of everyday events: A study of cutting and breaking. Cognition 109(2). 235-250.

Majid, Asifa, Melissa Bowerman, Sotaro Kita, Daniel B. M. Haun \& Stephen C. Levinson. 2004. Can language restructure cognition? The case for space. Trends in Cognitive Sciences 8(3), 108-114. doi:10.1016/j.tics.2004.01.003.

Majid, Asifa, Melissa Bowerman, Miriam van Staden \& James S. Boster. 2007. The semantic categories of cutting and breaking events: A crosslinguistic perspective. Cognitive Linguistics 18(2), 133-152.

Malt, Barbara C., Eef Ameel, Mutsumi Imai, Silvia P. Gennari, Noburo Saji \& Asifa Majid. 2014. Human locomotion in languages: Constraints on moving and meaning. Journal of Memory and Language 74, 107-123. doi:10.1016/j.jml.2013.08.003.

Malt, Barbara C. \& Asifa Majid. 2013. How thought is mapped into words. Wiley Interdisciplinary Reviews: Cognitive Science 4(6), 583-597. doi:10.1002/wcs.1251. 
Matlock, Teenie. 2004. Fictive motion as cognitive simulation. Memory \& Cognition 32(8), 1389-1400.

Matsumoto, Yo. 2001. Lexicalization patterns and caused and fictive motion: The case of typological split. Lecture at SUNY Buffalo, NY.

Michaelis, Laura A. 2004. Type shifting in construction grammar: An integrated approach to aspectual coercion. Cognitive linguistics 15(1), 1-68.

Miller, George A. \& Philip N. Johnson-Laird. 1976. Language and perception. Cambridge, MA: Belknap Press of Harvard University Press.

Murphy, M. Lynne. 2003. Semantic relations and the lexicon: Antonymy, synonymy, and other paradigms. Cambridge: Cambridge University Press.

Newman, John. 2009. A cross-linguistic overview of 'eat' and 'drink'. In John Newman (ed.), The linguistics of eating and drinking (Typological Studies in Language vol. 84), 1-26. Amsterdam: John Benjamins.

Norcliffe, Elisabeth, N. J. Enfield, Asifa Majid \& Stephen C. Levinson. 2010. The grammar of perception. In Elisabeth Norcliffe \& N. J. Enfield (eds.), Field manual volume, vol. 13, 7-16. Nijmegen: Max Planck Institute for Psycholinguistics.

Rappaport Hovav, Malka. 2014. Building scalar changes. In Artemis Alexiadou, Hagit Borer \& Florian Schäfer (eds.), The syntax of roots and the roots of syntax (Oxford Studies in Theoretical Linguistics), 259-281. Oxford: Oxford University Press.

Rappaport Hovav, Malka \& Beth Levin. 2010. Reflections on manner/result complementarity. In Malka Rappaport Hovav, Edit Doron \& Ivy Sichel (eds.), 
Lexical Semantics, Syntax, and Event Structure, vol. 1, 21-39. Oxford: Oxford University Press.

Selimis, Stathis \& Demetra Katis. 2010. Motion descriptions in English and Greek: A cross-typological developmental study of conversations and narratives. Linguistik online 42(2).

Slobin, Dan I. 2001. Form-function relations. In Melissa Bowerman \& Stephen C. Levinson (eds.), Language acquisition and conceptual development (Language, Culture and Cognition 3), 406-449. Cambridge: Cambridge University Press.

Slobin, Dan I. 2004. The many ways to search for a frog: Linguistic typology and the expression of motion events. In Sven Strömqvist \& Ludo Verhoeven (eds.), Relating events in narrative: Typological and contextual perspectives, vol. 2, 219-257. Mahwah, NJ: Erlbaum.

Slobin, Dan I. 2009. Relations between paths of motion and paths of vision: A crosslinguistic and developmental exploration. In Virginia C. MuellerGathercole (ed.), Routes to language: Studies in honor of Melissa Bowerman. New York: Psychology Press.

Slobin, Dan I. \& Nini Hoiting. 1994. Reference to movement in spoken and signed languages: Typological considerations. Proceedings of the 20th Annual Meeting of the Berkeley Linguistics Society, 487-505. Berkeley: Berkeley Linguistics Society.

Stefanowitsch, Anatol \& Ada Rohde. 2004. The goal bias in the encoding of motion events. In Klaus-Uwe Panther \& Gunter Radden (eds.), Studies in linguistic motivation, 249-268. Berlin: Mouton de Gruyter. 
Svenonius, Peter. 2010. Spatial p in English. In Guglielmo Cinque \& Luigi Rizzi (eds.), Mapping spatial PPs: The cartography of syntactic structures (Oxford Studies in Comparative Syntax), vol. 6, 127-160. Oxford: Oxford University Press.

Takahashi, Kiyoko. 2000. Expressions of emanation fictive motion events in Thai. $\mathrm{PhD}$ dissertation, Chulalongkorn University.

Talmy, Leonard. 1985. Lexicalization patterns: Semantic structure in lexical forms. In Timothy Shopen (ed.), Language typology and syntactic description: Vol. III, Grammatical categories and the lexicon, 55-149. Cambridge: Cambridge University Press.

Talmy, Leonard. 1991. Path to realization: A typology of event conflation. Proceedings of the 17th Annual Meeting of the Berkeley Linguistics Society, vol. 17, 480519. Berkeley: Berkeley Linguistics Society.

Talmy, Leonard. 2000a. Toward a cognitive semantics: Typology and process in concept structuring (Language, Speech, and Communication). Vol. 2. Cambridge, MA: MIT Press.

Talmy, Leonard. 2000b. Toward a cognitive semantics: Concept structuring systems (Language, Speech, and Communication). Vol. 1. Cambridge, MA: MIT Press. Thompson, Bill, Seán G. Roberts \& Gary Lupyan. 2020. Cultural influences on word meanings revealed through large-scale semantic alignment. Nature Human Behaviour. Nature Publishing Group, 1-10. doi:10.1038/s41562-020-0924-8.

Viberg, Åke. 1984. The verbs of perception: A typological study. Linguistics 21(1), 123-162. doi:10.1515/ling.1983.21.1.123.

Wnuk, Ewelina. 2016a. Semantic specificity of perception verbs in Maniq. $\mathrm{PhD}$ dissertation, Radboud University Nijmegen. 
Wnuk, Ewelina. 2016b. Specificity at the basic level in event taxonomies: The case of Maniq verbs of ingestion. In Anna Papafragou, Dan Grodner, Dan Mirman \& John Trueswell (eds.), Proceedings of the 38th Annual Meeting of the Cognitive Science Society, 2687-2692. Austin, TX: Cognitive Science Society.

Zlatev, Jordan \& Peerapat Yangklang. 2004. A third way to travel. In S. Strömqvist \& L. Verhoeven (eds.), Relating events in narrative: Typological and contextual perspectives, 191-218. Mahwah, NJ: Lawrence Erlbaum Associates.

Author's address: Department of Anthropology, University College London, 14 Taviton St, London WC1H OBW, United Kingdom e.wnuk@ucl.ac.uk 
FOOTNOTES

${ }^{1}$ I thank Asifa Majid, Stephen Levinson, Niclas Burenhult, Lila San Roque, Carolyn O'Meara, Rebecca Defina, and Josje de Valk, and three anonymous JL reviewers for comments, Elisabeth Norcliffe for stimulating discussions, and Kukiat Tudpor for Thai translations. This research was supported by the Max-Planck-Gesellschaft. Interlinear glosses follow the Leipzig Glossing Rules wherever possible, with the sole exception of MULT 'multiplicity (iterative/distributive)'.

${ }^{2}$ Other types of fictive motion distinguished by Talmy (2000b) include: coextension paths, pattern paths, frame-relative motion, advent paths, and access paths. For work on mental simulation during the processing of fictive motion descriptions, see Matlock (2004).

3 'With foot placed flat against tree, climber leans back to generate counter-pressure, advancing arms and feet alternately' (Kraft, Venkataraman \& Dominy 2014: 4, see also figure $1 \mathrm{H}$ on p. 3 ).

${ }^{4}$ The age of participants is estimated since the Maniq do not keep birth date records.

${ }^{5}$ Balay (and other visual perception verbs discussed here) can occur within multi-verb constructions. They can take arguments, but do not require them for grammaticality.

The verb-argument relationship in these types of multi-verb constructions is not marked grammatically but is established on a semantic basis.

${ }^{6}$ For a review of the frame-of-reference distinctions applied across different disciplines, see Levinson (2003: 25-34).

${ }^{7}$ Note that even though some stimuli were intended to be mirror images of each other (e.g. \#6 RIGHT_just_eyes and \#17 LEFT_just_eyes), they still differed with minute visual detail and did not always elicit predictably similar responses. Those minute differences may have primed the participants to attend to different aspects of the scene and use different linguistic construals. The differing response patterns may also to some extent be due to random effects.

${ }^{8}$ The only instances of explicit marking of boundary crossing in the whole data set was the phrase da? ncy 'inside' (LOC-inside) used by 2 participants to describe the scene of looking-INTO-room (\#41).

${ }^{9}$ It is worth noting that there is another verb with a meaning similar to piwe, often employed in similar contexts and enacted in similar ways. This verb - pils - is also a fossilized causative form, derived from the obsolete root* $l^{\prime}$ (present in cils 'to hide'). Further probing is needed to establish how these two verbs differ.

${ }^{10}$ According to Talmy's fictive motion framework (Talmy 2000b; Slobin 2009;

Cifuentes-Férez 2014), cikiey, ciyc̃k and cakip encode the DEIXIS path component, while balay, yop and pontew encode the EARTH-GRID DISPLACEMENT component.

${ }^{11}$ No explicit hyponymy test has been performed with Maniq speakers, but it is likely it would result in oddly-sounding sentences, e.g. one translating as 'Looking up is a kind/way of seeing' or - applying a special hyponymy frame proposed for verbs (Lyons 1977: 294) - 'To look up is to see, in a certain way'.

12 Note, however, that the progressive-cum-imperfective form $m-<\eta>d \varepsilon \eta$ 'to be looking' (PROG-<IPFV>look) - frequent in the picture naming task - is telic. This is related to the fact that progressive - although itself marking an unbounded situation implies the presence of situational boundaries (cf. Wnuk 2016a: 82; Michaelis 2004).

${ }_{13}$ More fine-grained distinctions in motion compared to vision could be argued to be expected since motion can be considered a more 'primary' domain. 